\title{
Ocean acidification alters morphology of all otolith types in Clark's anemonefish (Amphiprion clarkii)
}

Robert J Holmberg ${ }^{\text {Corresp., }}{ }^{1}$ ， Eric Wilcox-Freeburg ${ }^{1}$ ， Andrew L Rhyne ${ }^{2}$ ， Michael F Tlusty ${ }^{1}$, Alan Stebbins ${ }^{1}$, Steven W Nye Jr. ${ }^{1}$, Aaron Honig ${ }^{1}$, Amy E Johnston ${ }^{1}$, Christine M San Antonio ${ }^{1}$, Bradford Bourque ${ }^{2}$, Robyn E Hannigan ${ }^{1}$

\footnotetext{
${ }^{1}$ School for the Environment, University of Massachusetts at Boston, Boston, Massachusetts, United States

2 Department of Biology, Marine Biology and Environmental Science, Roger Williams University, Bristol, Rhode Island, United States

Corresponding Author: Robert J Holmberg

Email address: Robert.Holmberg001@umb.edu
}

Ocean acidification, the ongoing decline of surface ocean $\mathrm{pH}$ and $\left[\mathrm{CO}_{3}{ }^{2-}\right]$ due to absorption of surplus atmospheric $\mathrm{CO}_{2}$, has far-reaching consequences for marine biota, especially calcifiers. Among these are teleost fishes, which internally calcify otoliths, critical elements of the inner ear and vestibular system. There is evidence in the literature that ocean acidification increases otolith size and alters shape, perhaps impacting otic mechanics and thus sensory perception. Here, larval Clark's anemonefish, Amphiprion clarkii (Bennett, 1830), were reared in various seawater $\mathrm{pCO}_{2} / \mathrm{pH}$ treatments analogous to future ocean scenarios. At the onset of metamorphosis, all otoliths were removed from each individual fish and analyzed for treatment effects on morphometrics including area, perimeter, and circularity; scanning electron microscopy was used to screen for evidence of treatment effects on lateral development, surface roughness, and vaterite replacement. The results corroborate those of other experiments with other taxa that observed otolith growth with elevated $\mathrm{pCO}_{2}$, and provide evidence that lateral development and surface roughness increased as well. Both sagittae exhibited increasing area, perimeter, lateral development, and roughness; left lapilli exhibited increasing area and perimeter while right lapilli exhibited increasing lateral development and roughness; and left asterisci exhibited increasing perimeter, roughness, and ellipticity with increasing $\mathrm{pCO}_{2}$. Right lapilli and left asterisci were only impacted by the most extreme $\mathrm{pCO}_{2}$ treatment, suggesting they are resilient to any conditions short of aragonite undersaturation, while all other impacted otoliths responded to lower concentrations. Finally, fish settlement competency at $10 \mathrm{dph}$ was dramatically reduced, and fish standard length marginally reduced with increasing $\mathrm{pCO}_{2}$. Increasing abnormality and asymmetry of otoliths may impact inner ear function by altering otolith-maculae interactions. 


\section{AUTHOR COVER PAGE}

2

3 TITLE

4

5 Ocean acidification alters morphology of all otolith types in Clark's anemonefish (Amphiprion

6 clarkii)

8 AUTHOR NAMES

9

10 Robert J Holmberga, Eric Wilcox-Freeburga, Andrew L Rhyne ${ }^{\mathrm{b}}$, Michael F Tlusty ${ }^{\mathrm{a}}$, Alan

11 Stebbins $^{\mathrm{a}}$, Steven W Nye Jr. ${ }^{\mathrm{a}}$, Aaron Honig ${ }^{\mathrm{a}}$, Amy E Johnston ${ }^{\mathrm{a}}$, Christine M San Antonio ${ }^{\mathrm{a}}$,

12 Bradford Bourque $^{\mathrm{b}}$, Robyn E Hannigan ${ }^{\mathrm{a}}$

13

\section{AUTHOR AFFILIATIONS}

aSchool for the Environment, University of Massachusetts Boston, 100 William T Morrissey

17 Blvd, Boston, MA 02125

18 bepartment of Biology, Marine Biology and Environmental Science, Roger Williams

19 University, 1 Old Ferry Rd, Bristol, RI 02809

21 CORRESPONDING AUTHOR

23 Robert J Holmberg

24 Robert.Holmberg001@umb.edu 
25 ABSTRACT

27 Ocean acidification, the ongoing decline of surface ocean $\mathrm{pH}$ and $\left[\mathrm{CO}_{3}{ }^{2-}\right]$ due to absorption of surplus atmospheric $\mathrm{CO}_{2}$, has far-reaching consequences for marine biota, especially calcifiers. Among these are teleost fishes, which internally calcify otoliths, critical elements of the inner ear

and vestibular system. There is evidence in the literature that ocean acidification increases otolith size and alters shape, perhaps impacting otic mechanics and thus sensory perception. Here, larval Clark's anemonefish, Amphiprion clarkii (Bennett, 1830), were reared in various seawater $\mathrm{pCO}_{2} / \mathrm{pH}$ treatments analogous to future ocean scenarios. At the onset of metamorphosis, all otoliths were removed from each individual fish and analyzed for treatment effects on morphometrics including area, perimeter, and circularity; scanning electron microscopy was used to screen for evidence of treatment effects on lateral development, surface roughness, and vaterite replacement. The results corroborate those of other experiments with other taxa that observed otolith growth with elevated $\mathrm{pCO}_{2}$, and provide evidence that lateral development and surface roughness increased as well. Both sagittae exhibited increasing area, perimeter, lateral development, and roughness; left lapilli exhibited increasing area and perimeter while right lapilli exhibited increasing lateral development and roughness; and left asterisci exhibited increasing perimeter, roughness, and ellipticity with increasing $\mathrm{pCO}_{2}$. Right lapilli and left asterisci were only impacted by the most extreme $\mathrm{pCO}_{2}$ treatment, suggesting they are resilient to any conditions short of aragonite undersaturation, while all other impacted otoliths responded to lower concentrations. Finally, fish settlement competency at $10 \mathrm{dph}$ was dramatically reduced, and fish standard length marginally reduced with increasing $\mathrm{pCO}_{2}$. Increasing abnormality and asymmetry of otoliths may impact inner ear function by altering otolith-maculae interactions.

\section{INTRODUCTION}

Since the advent of the industrial revolution, humankind has inadvertently relocated a significant volume of carbon to the troposphere, where it now resides as a greenhouse gas, warming the earth via radiative forcing (IPCC, 2013). Global warming, however, is not the sole consequence of surplus atmospheric $\mathrm{CO}_{2}$ : the surface ocean has absorbed approximately $30 \%$ of 
56 to ocean acidification (Caldeira and Wickett, 2003). While this absorption is an important sink,

57 abating the greenhouse effect (IPCC, 2013), it has consequences for marine ecosystems.

58 Following diffusion, aqueous $\mathrm{CO}_{2}$ impacts seawater chemistry by reducing $\mathrm{pH}$ and carbonate

$59\left(\mathrm{CO}_{3}{ }^{2-}\right)$ concentration (Doney et al., 2009). Both will impact the fitness of marine biota, with

60 cascading effects up to the ecosystem level (Fabry et al., 2008; Queirós et al., 2015; Hoegh-

61 Guldberg et al., 2017). From population abundances to community shifts, ocean acidification has

62 the potential to alter the ecological landscape of the ocean (Gaylord et al., 2015).

The declining availability of free $\mathrm{CO}_{3}{ }^{2-}$ is particularly worrisome due to its implications

64 for marine calcifiers, which use calcium carbonate $\left(\mathrm{CaCO}_{3}\right)$ to form body structures including shells, teeth, and spines. Surface waters are normally supersaturated with $\mathrm{CO}_{3}{ }^{2-}$, but as $\left[\mathrm{CO}_{3}{ }^{2-}\right]$

66 decreases, calcifiers may struggle to precipitate $\mathrm{CaCO}_{3}$ (Gattuso and Buddemeier, 2000).

67 Furthermore, if seawater is undersaturated with respect to calcium carbonate minerals (e.g. aragonite, $\Omega_{\mathrm{Ar}}$ ), existing structures may readily dissolve (Orr et al., 2005). A vast body of literature expounds ocean acidification's anticipated effects on calcifier fitness in the future ocean, demonstrating variable degrees of severity (Hendriks et al., 2010; Kroeker et al., 2013). Differential responses may depend on the specific biochemical pathways involved in calcification (Ries et al., 2009), biological mechanisms for buffering $\mathrm{pH}$ changes in body fluids (Munday et al., 2011a), energetics limiting physiological acclimation (Seibel et al., 2012), or various ecological forces acting on an organism (Kroeker et al., 2012).

Teleostei is an extremely diverse infraclass of Actinopterygii representing the modern bony fishes, comprised of more than 30,000 species and dominating most aquatic habitats (Froese and Pauly, 2018). Teleosts are internal calcifiers, precipitating $\mathrm{CaCO}_{3}$ in the intestinal lumen that aids water absorption and osmoregulation (Grosell, 2011), and precipitating otoliths in the inner ear that are critical for mechanoreception (Moyle and Cech, 2004). Heuer and Grosell (2014) reviewed numerous effects of acidification on marine teleosts, including respiratory acidosis leading to sustained elevation of blood plasma $\mathrm{HCO}_{3}{ }^{-}$(Esbaugh et al., 2012), cognitive disruption and behavioral changes linked to inhibited $\mathrm{GABA}_{\mathrm{A}}$ neurotransmitter receptor function (Nilsson et al., 2012), mixed impacts on standard and maximum metabolic rates with implications for aerobic scope (Munday et al., 2009), and increased otolith area 
86 vulnerability for teleosts in the near-future ocean (Ishimatsu et al., 2008; Munday et al., 2008;

87 Heuer and Grosell, 2014).

Otoliths, or ear stones, are critical features located within the inner ear of teleost fishes,

89 formed by precipitation of $\mathrm{CaCO}_{3}$ around a protein-rich matrix and bathed in endolymph

90 (Panella, 1971). $\mathrm{CaCO}_{3}$ supersaturation is maintained in the endolymph by proton pumps in the

91 epithelial cells adjacent to the site of crystallization, which maintain the $\mathrm{pH}$ gradient required for

$92 \mathrm{CO}_{3}{ }^{2-}-\mathrm{HCO}_{3}{ }^{-}$balance (Ishimatsu et al., 2008). Otoliths exist in three pairs (sagittae, lapilli,

93 asterisci), with one from each pair contained within each otolithic end organ. When disturbed by

94 fish movement or sound waves, otoliths trigger sensory maculae lining the interior wall of their

95 chambers, converting the force into electrical impulses interpreted by the brain. Likewise,

96 otoliths function as sensory organs for hearing and gravisense (Popper and Fay, 1993).

Researchers recognize the potential for ocean acidification to impact otolith growth in teleosts, especially during the sensitive larval phase, and many have demonstrated effects experimentally (Table 1). Contrary to the hypothesis that ocean acidification will inhibit otolith growth due to dwindling $\mathrm{CO}_{3}{ }^{2-}$ availability (Ishimatsu et al., 2008), elevated seawater $\mathrm{pCO}_{2}$ stimulates growth of sagittae and/or lapilli in many taxa. This growth is attributed to elevated blood plasma $\left[\mathrm{HCO}_{3}^{-}\right]$, retained to buffer acidosis and transported into the endolymph where it becomes substrate for $\mathrm{CO}_{3}{ }^{2-}$ aggregation (Checkley et al., 2009; Munday et al., 2011b; Heuer and Grosell, 2014). Only one study (Mu et al. 2015) observed decreased otolith size in response to elevated $\mathrm{pCO}_{2}$. Other studies (Franke and Clemmesen, 2011; Munday et al., 2011a; Simpson et al., 2011; Frommel et al., 2013; Perry et al, 2015; Cattano et al., 2017; Martino et al., 2017; Jarrold and Munday, 2018) observed no effects of $\mathrm{pCO}_{2}$ on otolith morphology.

Evidence that acidification alters otolith size and shape has inspired hypotheses that this could interfere with otic mechanics, and thus impair sensory perception in teleosts (e.g. Munday et al., 2011b; Bignami et al., 2013b, 2014). Indeed, there is some evidence that asymmetry of otolith size, shape, and mass may impair auditory/vestibular function in some species with consequences for habitat detection and overall fitness (Lychakov and Rebane, 2005; Gagliano et

113 al., 2008; Anken et al., 2017). Others have added that increased otolith size from ocean

114 acidification could enhance auditory sensitivity to the benefit or detriment of the fish depending

115 on life history (Bignami et al., 2013b, 2014; Réveillac et al., 2015). 
While most available studies quantified simple morphometrics to analyze $\mathrm{pCO}_{2}$ effects

117

118

119

120

121

122

123

124

125

126

127

128

129

130

131

132

133

134

135

136

137

138

139

140

141

142

143

144

\section{5}

146

on otolith morphology, the most informative among them augmented morphometrics with other analyses, including complex shape analyses (e.g. Fourier analysis) (Munday et al., 2011a,b; Simpson et al., 2011; Martino et al., 2017; Mirasole et al., 2017); mass, volume and density analyses (Bignami et al. 2013a,b); and compositional analyses (e.g. LA-ICPMS) (Munday et al., 2011b; Hurst et al., 2012; Martino et al., 2017; Mirasole et al., 2017; Coll-Lladó et al., 2018). Similarly, scanning electron microscopy can be used to screen for treatment effects on aspects of otolith morphology and composition that, although typically overlooked in simple morphometric analysis, may impact ear function. These may include: (i) lateral development, defined as the degree of convexity of an otolith's lateral face; (ii) percent visible crystals, defined as an estimate of surface crystal density or grain, approximating surface roughness; (iii) crystal habit, here defined as any deviation in crystal shape from the predominant orthorhombic aragonite in sagittae and lapilli, or hexagonal vaterite in asterisci; and (iv) overall mineralogy, here defined as relative proportion of orthorhombic aragonite versus hexagonal vaterite visible on an otolith's surface. The former two metrics estimate an otolith's surface topography and texture, and the latter two estimate crystal features indicative of composition, density, and stability under environmental stress (Boulos et al., 2014). These metrics are intended as first-pass screening tools for efficiently identifying general trends in the data; should they yield compelling evidence of treatment differences, they could be followed with more rigorous methods to best quantify the variable (e.g., measuring otolith height directly or determining $\mathrm{CaCO}_{3}$ polymorph composition with Raman spectroscopy (Coll-Lladó et al., 2018)).

In addition to standard morphometrics, the mineralogical metrics described above were used to investigate ocean acidification impacts on otolith morphology in larval Clark's anemonefish, Amphiprion clarkii (Bennett, 1830). A. clarkii is a teleost reef fish belonging to Pomacentridae and inhabiting shallow reefs throughout the Indo-Pacific (Froese and Pauly, 2018). The species was chosen both as a novel taxon and to enable intragenus comparison with previous work (Munday et al., 2011b). Any impacts on its otolith morphology could have implications for teleost sensory perception and fitness in the future ocean.

\section{MATERIALS \& METHODS}


147 Livestock: All husbandry was completed at Roger Williams University in Bristol, Rhode Island, 148 USA (IACUC \#R-11-09-13). Several Amphiprion clarkii (Bennett, 1830) broodstock pairs were 149 reared, all wild-caught in Fiji and acquired from Long Island Aquarium, Riverhead, New York,

150 USA. Broodstock periodically laid clutches of eggs on porcelain tiles in aquaria (every 10-12 151 days). One large, healthy clutch was selected from a single broodstock pair, removed the night

152 before anticipated day of hatch (around day eight post-deposition), and placed it in a separate, 153 aerated, $200 \mathrm{~L}$ hatching aquarium. Upon hatch, $A$. clarkii larvae were randomly distributed into

$15440 \mathrm{~L}$ experimental aquaria at a density of 40 individuals per aquarium. Throughout the

155 experimental trial, larvae were fed ad libitum with wild copepods from monoculture

156 (Pseudodiaptomus spp.) in a background of algae (Isochrysis spp.). Pseudodiaptomus spp. were 157 dosed to densities of $5 \mathrm{~mL}^{-1}$ and $1 \mathrm{~mL}^{-1}$ (nauplii and adults respectively), as measured using a 158 counting wheel, and Isochrysis spp. twice daily to maintain a concentration of 40,000 cells $\mathrm{mL}^{-1}$, 159 as measured using a cell counter (Beckman Coulter Inc., Brea, CA).

161 Experimental Trial: The experimental design consisted of four $\mathrm{pCO}_{2} / \mathrm{pH}$ treatments selected to 162 model various present and anticipated future ocean conditions: (i) $350 \mu \mathrm{atm} / \mathrm{pH} 8.16$ (control), 163 modern ocean conditions; (ii) $800 \mu \mathrm{atm} / \mathrm{pH} 7.80$, approximate conditions projected for 2100 164 under Representative Concentration Pathway (RCP) 8.5 (IPCC, 2013); (iii) 1,600 $\mu \mathrm{atm} / \mathrm{pH} 7.60$, nearly double 2100 levels under RCP 8.5 (IPCC, 2013); (iv) 3,000 $\mu \mathrm{atm} / \mathrm{pH} 7.30$, a reasonable extreme given coastal eutrophication-induced acidification (Wallace et al., 2014), and given that eutrophication is already occurring in some reef systems inhabited by A. clarkii (Bell et al., 2014; Fabricius, 2005). Treatments were replicated three times and assigned to 12 experimental units (aquaria) in a randomized design. Seawater was sourced from Mt. Hope Bay, sterilized using sodium hypochlorite and UV light, filtered to $1 \mu \mathrm{m}$, and used to fill experimental aquaria. $25 \%$ water changes were completed every other day using drip buckets at $100 \mathrm{~mL} \mathrm{~min}^{-1}$. Seawater

172 salinity and temperature were measured twice daily in all aquaria using a handheld meter (YSI,

173 Yellow Springs, OH). Seawater total alkalinity was measured once every other day in all aquaria 174 using a tabletop autotitrator (Hanna Instruments, Smithfield, RI). The experimental trial took 175 place within an environmental chamber to maintain ambient air conditions at $28^{\circ} \mathrm{C}$, and aquaria 176 were covered with loose fitting lids to minimize $\mathrm{CO}_{2}$ outgassing and evaporative heat loss.

177 Seawater was aerated with house-supplied air connected to airstones to maintain dissolved 
178 oxygen. Experimental treatments were achieved and maintained by dosing $\mathrm{CO}_{2}$ gas through the 179 airstones using a $\mathrm{CO}_{2}$ dosing apparatus (Wilcox-Freeburg et al., 2013) controlled by hobbyist

180 aquarium controllers (Digital Aquatics, Woodinville, WA). $\mathrm{pH}_{\mathrm{T}}$ of each aquarium was measured 181 continuously using research-grade glass combination electrodes calibrated to synthetic seawater 182 buffers (Byrne, 1987; Millero et al., 1993), prepared from analytical reagent grade chemicals 183 (Fisher Scientific, Hampton, $\mathrm{NH}$ ). The aquarium controller output $\mathrm{pH}_{\mathrm{T}}$ data every 1-3 seconds 184 via RSS feed, which was parsed/logged to a PC with custom Perl and MATLAB scripts (Wilcox185 Freeburg, 2014) (Perl Version 5.28.0, https://www.perl.org/;

186 MATLAB Version R2017b, https://www.mathworks.com/products/matlab.html). Average DIC,

$187 \mathrm{pCO}_{2}$, and $\Omega_{\mathrm{Ar}}$ were calculated for each aquarium from measured seawater parameters using

188 CO2calc (https://soundwaves.usgs.gov/2011/03/research4.html). The experimental trial

189 concluded after 10 days, at the onset of fish metamorphosis.

190

191 Data Collection: Upon conclusion of the experimental trial, and following euthanization of fish with a lethal dose of tricaine mesylate (MS-222) in seawater, each individual was counted, placed on a Sedgewick rafter $(1 \mathrm{~mm})$, and photographed with a digital camera-equipped stereomicroscope at 10x-90x magnification. Mortality counts (by aquarium) were calculated by subtracting final fish counts from initial stocking density. Standard lengths of each individual were measured to $1 / 100 \mathrm{~mm}$ from stereomicrographs with ImageJ (Version 1.51n; https://imagej.nih.gov/ij/), and averaged by aquarium (arithmetic mean). Settlement competency was determined according to behavioral and morphological criteria; larvae were considered competent to settle when they began to cling to an aquarium wall rather than swim freely in the water column, and concurrently develop pigmentation consistent with settlement-stage metamorphosis. Due to natural variance in ontogeny among individuals, some had not achieved settlement competency when the experimental trial ended at 10 days post hatch (dph). Proportions of surviving fish that achieved settlement competency by $10 \mathrm{dph}$ versus those that had not were tallied for each aquarium. Non-settlement-stage fish data (standard length, otolith morphometric variables, otolith mineralogical variables) were excluded from all further analyses (sample exclusion criteria were pre-established; 38 fish, or roughly 15\% of surviving fish, were excluded). Next, all six otoliths (two each of sagittae, lapilli, and asterisci) were manually removed under a polarizing stereo dissection microscope. Each set of otoliths was digitally 
209 photographed with the stereomicroscope at 90x magnification and mounted to aluminum

210 scanning electron microscopy (SEM) stubs for later analysis. Area, perimeter, major axis, and

211 minor axis of all six otoliths from all fish were quantified from stereomicrographs with custom

212 MATLAB image analysis software (Wilcox-Freeburg, 2014) (MATLAB Version R2017b;

213 https://www.mathworks.com/products/matlab.html). All otolith morphometrics were measured to

$2141 / 100$ unit. Otolith circularity was calculated from major and minor axes $\left(\frac{\pi \times(\text { minor axis } / 2)^{2}}{\pi \times(\text { major axis } / 2)^{2}}\right)$.

215 Aquarium means for each morphometric variable were determined by calculating the arithmetic

216 mean of data from all individual fish within each aquarium (grouped by otolith type and side).

217 Due to moderate-strong correlations between standard length and otolith area and perimeter at

218 the evaluation unit (individual fish) level (area: $r>0.49$, perimeter: $r>0.30$ for all otolith

219 types/sides), otolith area and perimeter were normalized to standard length of individuals prior to

220 calculating aquarium means. This facilitated investigation of treatment effects while accounting

221 for potentially confounding differences in standard length between fish. Next, each individual

222 otolith was imaged with SEM in secondary electron mode using a working distance of $10 \mathrm{~mm}$,

223 spot size of 30 , accelerating voltage of $10 \mathrm{kV}$, and magnification up to 3,000x. Scanning electron

224 micrographs were scored visually for various mineralogy-related variables multiple times using

225 Qualtrics survey software (Version N/A; https://www.qualtrics.com/). Six trained, independent

226 readers scored variables including lateral development (scale of 1-5), crystal habit

227 (orthorhombic, hexagonal, acicular, acrystalline, amorphous), percent visible crystals (5-50\%),

228 and mineralogy (proportion aragonite/vaterite on an otolith's surface interpretable by crystal

229 habit) according to a rubric (see "Supplemental Rubric S4.pdf" for the rubric used to train and

230 guide readers through scoring ${ }^{1}$ ). The rubric contains reference illustrations (and in the case of the

231 lateral development variable, micrographs) for each metric and lists categories to choose from

232 for scoring; for each metric, the readers were asked to choose the option that best categorizes

233 each otolith. Poor-quality micrographs due to mounting errors or broken otoliths were marked as

234 unusable and not scored (41 micrographs, or roughly 4\% of all micrographs, were excluded).

235 Otolith-specific raw data grouped by type and side were generated for each variable from the

236 survey questions. Each individual otolith was assigned the mode of survey scores for each

237 variable. If a two-way mode tie occurred, the lower of the modes was selected. If a three-way

1 "Core development" in the rubric has been renamed "lateral development" in the manuscript. In the rubric, "core" refers not to the otolith's core but to the center of its lateral face. 
238 mode tie occurred, the median mode was selected. For the lateral development and percent

239 visible crystals variables, aquarium means were determined by calculating the arithmetic mean

240 of the survey response mode for each otolith type and side, thus generating approximately

241 continuous aquarium means from ordinal data (Norman, 2010). The mineralogy and crystal habit

242 variables are nominal, so aquarium means were determined by calculating the mode of the

243 otolith modes. See "Supplemental Data S1.csv" for data means to be subset by otolith type/side

244 and "Supplemental Data S2.csv" for raw, fish-level data.

246 Statistical Analyses: Hypothesis tests were used to identify and interpret any impacts of

247 increasing seawater $\mathrm{pCO}_{2}$ on otolith morphology in each otolith type/side, as well as on fish

248 mortality, settlement competency, and standard length. All statistical analyses were conducted

249 using R (Version 3.4.3; https://www.r-project.org/; see "Supplemental Code S3.R" for analyses).

250 Regression analyses $\left(\mathrm{pCO}_{2}\right.$ as a continuous variable) were selected over ANOVA with multiple

251 comparisons ( $\mathrm{pCO}_{2}$ as a grouping factor) for their greater power, informativeness, parsimony,

252 and appropriateness for interpreting linear dose-response relationships (Lazic, 2008). Polynomial

253 models were considered for all regression analyses, and model selection performed using

254 goodness of fit tests (i.e., F-tests for general linear models and chi-squared tests for generalized

255 linear models). All binomial logistic regression models were tested for overdispersion. All

256 statistical tests were two-tailed. The crystal habit and mineralogy response variables exhibited no

257 variance across any treatment and otolith type, so they were excluded them from further

258 analyses. Principal component analysis (PCA) was performed on aquarium means for each

259 otolith type and side. PCA was run on the correlation matrix between the morphometric (area,

260 perimeter, circularity) and survey (lateral development, percent visible crystals) response

261 variables using varimax rotation. Components with eigenvalues greater than or equal to 1.0 were

262 retained. Treatment effects of $\mathrm{pCO}_{2}$ on otolith morphometrics were investigated with regression

263 analysis, with component scores as the response variables and $\mathrm{pCO}_{2}$ as the explanatory variable.

264 Regression analysis was performed on all components representing all otolith types and sides,

265 and models in which $\mathrm{pCO}_{2}$ predicted component scores $(\mathrm{p}<0.05)$ were retained. Treatment

266 effect on fish mortality was investigated with binomial logistic regression analysis (link function

267 = logit), with the proportion of mortality counts (per aquarium)/aquarium stocking density as the

268 response variable and $\mathrm{pCO}_{2}$ as the explanatory variable. Treatment effect on somatic growth was 
269 investigated with regression analysis, with mean fish standard length $(\mathrm{mm})$ as the response

270 variable and $\mathrm{pCO}_{2}$ as the explanatory variable. Treatment effect on settlement competency at 10

271 dph was investigated with binomial logistic regression analysis, with the proportion of competent

272 (per aquarium)/remaining fish (per aquarium) at the end of the experimental trial as the response

273 variable and $\mathrm{pCO}_{2}$ as the explanatory variable. For all regression analyses that predicted an effect

274 of $\mathrm{pCO}_{2}$, truncated models were created that are identical except that data from the 3,000 $\mu \mathrm{atm}$

$275 \mathrm{pCO}_{2} / \mathrm{pH} 7.30$ treatment were excluded; this enabled interpretation of the models without the

276 influence of this most extreme treatment, with the caveat that they employ $n$ fewer degrees of

277 freedom and are thus less powerful than the full models. For the truncated models, only F- and p-

278 values are reported, as the full models were considered to be otherwise more informative.

279

280 RESULTS

281

282 Seawater Carbonate Chemistry:

283

$284 \mathrm{pH}$ treatments remained on target throughout the experimental trial (standard deviation $\leq 0.4$ )

285 (Table 2).

286

287 Otolith Morphometrics and Scoring:

288

289

Otolith morphometrics and mineralogical metrics varied with $\mathrm{pCO}_{2}$ treatment and

290 according to otolith type and side (Fig. 1). Scoring for the crystal habit and mineralogy metrics never deviated from the norm for any otolith type in any treatment (i.e., sagittae and lapilli were

292 consistently scored as predominantly aragonitic, exhibiting orthorhombic crystal habit; asterisci were assumed to be vateritic despite exhibiting little to no identifiable crystal habit).

Principal Component Analysis:

296 
For each otolith type and side, principal component analysis produced two components

298

299

300

301

302

303

304

305

306

307

308

309

310

311

312

313

314

315

316

317

318

319

320

321

322

323

324

325

326

327 with eigenvalues greater than 1.0 (Table 3). From here on, the components are referred to as rotated components - $\mathrm{RC} 1$ or $\mathrm{RC} 2$ - to reflect that their loadings were scaled with varimax rotation. Left Sagittae (LS): As $\mathrm{pCO}_{2}$ increased, left sagittae were rendered overall larger and wider in circumference, with more pronounced lateral faces and rougher surface textures owed to greater visible crystal density (Tables 3,4; Fig. 2A). Right Sagittae (RS): As $\mathrm{pCO}_{2}$ increased, right sagittae responded according to the same metrics as left sagittae, albeit with slightly stronger responses of area/SL and perimeter/SL (Tables 3,4; Fig. 2B). Whereas left sagittae responses were best represented as a linear model, right sagittae responses were best represented as a curvilinear (quadratic) model, with responses leveling out between the $1,600 \mu \mathrm{atm} \mathrm{pCO}_{2} / \mathrm{pH}$ 7.60 and 3,000 $\mu \mathrm{atm} \mathrm{pCO}_{2} / \mathrm{pH} 7.30$ treatments. Left lapilli (LL): As $\mathrm{pCO}_{2}$ increased, left lapilli were rendered larger and wider in circumference (Tables 3,4; Fig. 2C). Right Lapilli (RL): In the most extreme $\mathrm{pCO}_{2}$ treatment only, right lapilli were rendered rougher with more pronounced lateral faces despite remaining approximately the same size (Tables 3,4; Fig. 2D). Whereas left lapilli responses were best represented as a curvilinear (quadratic) model, with responses leveling out between the $1,600 \mu \mathrm{atm} \mathrm{pCO}_{2} / \mathrm{pH} 7.60$ and $3,000 \mu \mathrm{atm} \mathrm{pCO}_{2} / \mathrm{pH} 7.30$ treatments, right lapilli responses were best represented as a linear model. Left Asterisci (LA): In the most extreme $\mathrm{pCO}_{2}$ treatment only, left asterisci were rendered increasingly elliptical (rather than circular), rougher, and wider in circumference (Tables 3,4; Fig. 2E). This was the only instance of 2-dimensional otolith shape change observed in response to treatment, as well as the only otolith metric that decreased rather than increased with increasing $\mathrm{pCO}_{2}$. Right Asterisci (RA): Right asterisci were not observed to respond to increasing $\mathrm{pCO}_{2}$ (Fig. 2F). This was the only otolith type/side that exhibited no response to treatment.

\section{Mortality, Settlement Competency, and Somatic Growth:}

Fish mortality, competency to settle at $10 \mathrm{dph}$, and standard length varied somewhat with $\mathrm{pCO}_{2}$ treatment (Fig. 3). Despite high fish mortality throughout the experimental trial, mortality was not associated with $\mathrm{pCO}_{2}$ (Table 4, Fig. 4A). As $\mathrm{pCO}_{2}$ increased, fewer fish were competent to settle at $10 \mathrm{dph}$ (Table 4, Fig. 4B). In the most extreme $\mathrm{pCO}_{2}$ treatment only, fish exhibited diminished somatic growth relative to those at lower concentrations (Fig. 4C). 
329

330

331

332

333

334

335

336

337

338

339

340

341

342

343

344

345

346

347

348

349

350

351

352

353

354

355

356

357

358

\section{DISCUSSION}

Otoliths exhibited diverse responses to treatment according to type and side. In response to increasing seawater $\mathrm{pCO}_{2}$, all three otolith types exhibited increasing perimeter and percent visible crystals, sagittae and lapilli exhibited increasing area and lateral development, and asterisci exhibited differences in shape. While the sagittae changed according to the same metrics regardless of side, the lapilli and asterisci changed according to different metrics depending on side. These differences reveal important things about the nature of the metrics under investigation; for example, while both sagittae responded to treatment by growing larger with more pronounced lateral faces, these effects were segregated according to side in the lapilli; this suggests that otolith area and lateral development are uncoupled rather than being two immutably conjoined metrics of growth. As such, it is often informative to investigate each otolith independently rather than investigating one type or pooling by type without regard to side. Among the 24 studies reviewed here that analyzed ocean acidification impacts on otolith morphology, five investigated lapilli (Table 1), none investigated asterisci, and eight segregated otoliths by side during morphometric analysis (at least six of which pooled them after observing no evidence of asymmetry) (Franke and Clemmesen, 2011; Munday et al., 2011a,b; Maneja et al., 2013; Bignami et al., 2014; Mu et al., 2015; Perry et al., 2015; Réveillac et al., 2015;

Martins, 2017; Jarrold and Munday 2018). However, the results suggest that responses of one or two otoliths cannot necessarily be extrapolated to the rest of the otolith system.

Some regression models were disproportionately weighted by the $3,000 \mu \mathrm{atm} \mathrm{pCO}_{2} / \mathrm{pH}$ 7.30 treatment, as evidenced by the p-value change between the full model and truncated model with data from that treatment excluded. Although the p-values for all otolith morphological models increased with truncation (Table 4, attributable in part to a loss of power from fewer degrees of freedom), the p-values for the right lapilli and left asterisci models rose $>0.05$, indicating there is little to no evidence of $\mathrm{pCO}_{2}$ impacts on those otoliths except in conditions of aragonite undersaturation. For the lapilli, this exercise indicates an asymmetry of resilience: left lapilli are impacted by lower $\mathrm{pCO}_{2}$ concentrations, whereas right lapilli are not. Nevertheless, this still results in morphological asymmetry of lapilli at lower concentrations. For the asterisci, it indicates mutual resilience at lower concentrations, and morphological asymmetry at the 
359 highest concentration. Scenarios in which these relationships are ecologically relevant could

360 include isolated coastal systems with poor mixing under additional pressure from eutrophication

361 (Wallace et al., 2014; Fabricius 2005) or volcanism (Vogel et al., 2015). However, lower

362 concentrations are here considered more typical of the future ocean.

363 Researchers previously examined otolith development in teleost larvae reared under

364 acidified conditions, and despite differences in methodology and model species, it is possible to

365 draw comparisons. Notably, Munday et al.'s (2011b) study species (Amphiprion percula) enables

366 intragenus comparison with $A$. clarkii. Here, the results are consistent with those of Munday et

367 al. (2011b) and several others (Table 1) in that sagittae grew at elevated seawater $\mathrm{pCO}_{2}$.

368 However, Munday et al. (2011b) observed growth in left sagittae only, whereas A. clarkii

369 exhibited growth in both sagittae. The results are further consistent with six of those studies

370 (Table 1) in that lapilli also grew at elevated $\mathrm{pCO}_{2}$ (albeit in the left ear only). Regarding otolith

371 shape: the results are consistent with five studies (Table 1) in that otolith shape changed at

372 elevated $\mathrm{pCO}_{2}$, albeit in left asterisci only, and only in conditions of aragonite undersaturation. A

373 caveat: whereas most other studies reared fish from two or more genotypes (e.g. Munday et al.,

374 2011a,b; Bignami et al., 2013a,b,2014), the present study used one clutch of eggs produced by

375 one broodstock pair. While this eliminated lineage as a potentially confounding variable in the

376 analysis, care should be taken when comparing the results of this study with others or

377 extrapolating to larger populations.

378 Some of the observed effects of seawater $\mathrm{pCO}_{2}$ on otolith growth in A. clarkii, including

379 increasing area, perimeter, and lateral development, may be consequences of acid-base

380 regulation triggered by respiratory acidosis. Fishes normalize internal $\mathrm{pH}$ disturbances by

381 metabolic adjustment: blood plasma $\mathrm{HCO}_{3}{ }^{-}$is absorbed/retained and $\mathrm{H}^{+}$excreted by modulating

382 rates of transport across the gill epithelium. However, extracellular $\mathrm{pCO}_{2}$ and $\mathrm{HCO}_{3}{ }^{-}$remain

383 elevated following $\mathrm{pH}$ adjustment, and excess $\mathrm{HCO}_{3}{ }^{-}$is imported to the endolymph where it

384 becomes substrate for $\mathrm{CO}_{3}{ }^{2-}$ aggregation, enhancing net otolith calcification (Checkley et al.,

385 2009; Munday et al., 2011b; Heuer and Grosell, 2014).

386 Since otoliths are critical components of the ears and vestibular organs (Fekete, 2003;

387 Moyle and Cech, 2004), ocean acidification-driven changes to otolith development may

388 challenge sensory perception in A. clarkii and other teleosts (e.g. Munday et al., 2011b; Bignami

389 et al., 2013b, 2014). Indeed, there is some empirical evidence outside the context of ocean 
390 acidification that marine fish exhibiting abnormal otolith morphology or asymmetry suffer

391 diminished sensory ability. In terms of hearing, fish with larger, vateritic, and/or otherwise

392 asymmetrical sagittae exhibited reduced sensitivity or deafness (Oxman et al., 2007; Gagliano et

393 al., 2008; Browning et al., 2012); some presumably because vaterite is less dense than aragonite,

394 thereby reducing otolith displacement amplitude and effectiveness in the inner ear (Bignami et

395 al., 2013b; Reimer et al., 2016). Although there remains no evidence of ocean acidification-

396 induced vaterite replacement in otoliths, including in $\mathrm{A}$. clarkii, there is some evidence for calcite

397 replacement in sagittae and lapilli at elevated $\mathrm{pCO}_{2}$ (Coll-Lladó et al., 2018); calcite is similarly

398 less dense than aragonite (Filho et al., 2014). In terms of kinesthesia, some fish with abnormal

399 and/or asymmetric sagittae/lapilli exhibited kinetoses (Söllner et al., 2003; Anken et al., 2017);

400 however, some studies observed $\mathrm{pCO}_{2}$ impacts on otolith morphology without observing impacts

401 on behavior (Bignami et al. 2013a, 2014; Shen et al., 2016). It is possible the $\mathrm{pCO}_{2}$ impacts on

402 otolith morphology and asymmetry observed here could impair $A$. clarkii hearing and

403 kinesthesia, but no sensory or behavioral assays were conducted, so hypotheses remain

404 speculative.

405 In addition to corroborating reports of otolith growth along the $\mathrm{x}$ and $\mathrm{y}$ axes (i.e.,

406 increasing area and perimeter) in young teleosts in response to increasing seawater $\mathrm{pCO}_{2}$, there

407 was evidence for $\mathrm{pCO}_{2}$-induced otolith growth along the z-axis (i.e., upward growth from the

408 lateral face) in A. clarkii. Lateral development appears most conspicuous in sagittae, and linked

409 to treatment in sagittae and right lapilli, although it was observable in asterisci as well. While

410 lateral development occurs on the lateral face, which does not directly interact with maculae, it is

411 possible this $\mathrm{CaCO}_{3}$ aggregation will increase otolith mass at a magnitude greater than that

412 which is evident from increased 2-dimensional area and perimeter. Thus, sagittae exhibiting

413 advanced lateral development may have a wider displacement amplitude independent of area and

414 perimeter, enhancing auditory sensitivity (Bignami et al., 2013b); however, displacement

415 amplitude was not measured here. This hypothesis is independent of otolith composition, for

416 which there was no evidence of having changed, but which undermined auditory sensitivity in

417 some studies (Oxman et al., 2007; Browning et al., 2012; Reimer et al., 2016). Also, since lateral

418 development appears to occur on only one face of the otolith (though the medial face was not

419 investigated here, all otoliths were imaged convex-side up, which was invariably the lateral

420 face), its center of mass likely changed as well, with unknown consequences for otic mechanics. 
Some of the otoliths appear visibly smooth on the surface, while others appear rougher

422 due to the exposure of aragonite table edges and similar crystal activity. Estimating percent

423 visible crystals is akin to estimating otolith surface roughness. The observation that percent

424 visible crystals increased with increasing $\mathrm{pCO}_{2}$ in sagittae, right lapilli, and left asterisci is

425 consistent with the characterization of rough-type otoliths as abnormal in other species (Béarez

426 et al., 2005; Ma et al., 2008; Browning et al., 2012). Increasing roughness could be a symptom of

427 haphazard $\mathrm{CaCO}_{3}$ aggregation, evidence of altered protein matrix deposition, or a snapshot of an

428 evolving $\mathrm{CaCO}_{3}$ crystal habit/polymorph baseline. While increasing roughness seems unlikely to

429 affect otolith displacement amplitude, it could conceivably impact otolith-maculae mechanics

430 with unknown consequences for function; in some fish, otoliths are observed to be rough on the

431 ventral end only, driving maculae deformation by hooking them to the otolith surface (Ohnishi et

432 al., 2002). More research concurrently investigating fish behavior, ocean acidification-induced

433 otolith roughness, and maculae displacement is needed to explore this hypothesis.

As might be expected when rearing many hundreds of fish in the most delicate early stages of development, Amphiprion clarkii larvae experienced substantial mortality throughout

436 the experimental trial. Although there is evidence in the literature of acute $\mathrm{CO}_{2}$ toxicity in larval

437 teleosts, this is typically observed at $\mathrm{pCO}_{2}$ levels far exceeding those evaluated here (i.e. $>$

438 48,000 uatm) (Kikkawa et al., 2003; Ishimatsu et al., 2004; Kikkawa et al., 2004); this is

439 consistent with the absence of evidence that treatment instigated fish mortality. The sublethal

440 impact of $\mathrm{pCO}_{2}$ on settlement competency at $10 \mathrm{dph}$, however, was dramatic. There is some

441 evidence of inhibited larval growth following delays in metamorphosis (Victor, 1986;

442 McCormick, 1999), and some degree of inhibited growth was observed here, but the present

443 analysis should be interpreted with caution due to the following caveats: (i) $10 \mathrm{dph}$ was selected

444 as the onset of metamorphosis and presumed settlement competency, but this threshold may be

445 arbitrary to metamorphosis and settlement completion; (ii) metamorphosis and response to

446 settlement cues may decouple at elevated seawater $\mathrm{pCO}_{2}$ (Rossi et al., 2015), complicating

447 metamorphosis as a reliable indicator for settlement competency; (iii) indeed, laboratory-reared

448 fish were unexposed to settlement cues including reef sounds, lunar phase, and anemone

449 presence; (iv) otolith microstructure evidence of settlement competency was not investigated; (v)

450 inhibited larval growth due to delayed metamorphosis isn't known to translate to inhibited

451 growth post-settlement (McCormick, 1999). Finally, the impact on somatic growth was 
452 marginal: the reduction in fish standard lengths with increasing $\mathrm{pCO}_{2}$ amounts to a small fraction

453 of fish standard lengths, and this effect was only relevant in conditions of aragonite

454 undersaturation.

455

456

\section{CONCLUSIONS}

457

458

459

460

seawater $\mathrm{pCO}_{2}$ reported for other taxa in a novel taxon, Amphiprion clarkii. In addition, it reports evidence of increasing otolith lateral development and surface roughness with increasing $\mathrm{pCO}_{2}$.

461 Impacts were observed in all otolith types, including the previously uninvestigated asterisci.

462 Each otolith type and side were investigated independently, indicating asymmetrical responses of 463 lapilli and asterisci to $\mathrm{pCO}_{2}$. The experimental design and analysis facilitated construction of $\mathrm{pCO}_{2}$ dose-response curves, which were created for all otolith types and sides in A. clarkii excepting right asterisci. These curves outline changes to multiple morphometric and mineralogical variables and may be leveraged to predict responses to $\mathrm{pCO}_{2}$ conditions not investigated here. These responses could impact auditory and/or vestibular sensitivity in teleosts, adding to previous observations and hypotheses involving sagittae and lapilli. In summary, the work adds to the existing knowledge base regarding otolith response to ocean acidification, which may aid in predicting and preserving teleost fitness in the near-future ocean.

\section{ACKNOWLEDGMENTS}

473

474 The authors would like to acknowledge Bill Robinson, Meng Zhou, Solange Brault, and Gene 475 Gallagher for advice and guidance; Bryanna Broadaway, Alex Eisen-Cuadra, Ashley Bulseco476 McKim, Jeremy Williams, Katie Flanders, and Nicole Henderson for assistance and support; and 477 undergraduates from Roger Williams University who assisted with the experimental trial and 478 data collection: Kristen Kiefer, Shawna Chamberlin, Jackie Mitchell, Drew Canfield, Allex 479 Gourlay, and Matt Muscara. 
480

481

482

483

484

485

486

487

488

489

490

491

492

493

494

495

496

497

498

499

500

501

502

503

504

505

506

507

508

509

510

\section{REFERENCES}

Anken, R. H. and Rahmann, H. (1999). Effect of altered gravity on the neurobiology of fish. Naturwissenschaften 86, 155-167.

Anken, R. H., Ibsch, M. and Rahmann, H. (1998). Neurobiology of fish under altered gravity conditions. Brain Res. Rev. 28, 9-18.

Anken, R., Knie, M. and Hilbig, R. (2017). Inner ear otolith asymmetry in late-larval cichlid fish (Oreochromis mossambicus, Perciformes) showing kinetotic behaviour under diminished gravity. Sci. Rep. 7, 15630.

Béarez, P., Carlier, G., Lorand, J. P. and Parodi, G. C. (2005). Destructive and nondestructive microanalysis of biocarbonates applied to anomalous otoliths of archaeological and modern sciaenids (Teleostei) from Peru and Chile. Comptes Rendus - Biol. 328, $243-$ 252.

Beier, M. (1999). On the influence of altered gravity on the growth of fish inner ear otoliths. Acta Astronaut. 44, 585-591.

Bell, P. R. F., Elmetri, I. and Lapointe, B. E. (2014). Evidence of large-scale chronic eutrophication in the Great Barrier Reef: Quantification of chlorophyll $a$ thresholds for sustaining coral reef communities. Ambio 43, 361-376.

Bignami, S., Sponaugle, S. and Cowen, R. K. (2013a). Response to ocean acidification in larvae of a large tropical marine fish, Rachycentron canadum. Glob. Chang. Biol. 19, 9961006.

Bignami, S., Enochs, I. C., Manzello, D. P., Sponaugle, S. and Cowen, R. K. (2013b). Ocean acidification alters the otoliths of a pantropical fish species with implications for sensory function. Proc. Natl. Acad. Sci. 110, 7366-7370.

Bignami, S., Sponaugle, S. and Cowen, R. K. (2014). Effects of ocean acidification on the larvae of a high-value pelagic fisheries species, Mahi-mahi Coryphaena hippurus. Aquat. Biol. 21, 249-260.

Boulos, R. A., Zhang, F., Tjandra, E. S., Martin, A. D., Spagnoli, D. and Raston, C. L. (2015). Spinning up the polymorphs of calcium carbonate. Sci. Rep. 4, 3616.

Browning, Z. S., Wilkes, A. A., Moore, E. J., Lancon, T. W. and Clubb, F. J. (2012). The effect of otolith malformation on behavior and cortisol levels in juvenile red drum fish 
511 (Sciaenops ocellatus). Comp. Med. 62, 251-256.

512 Byrne, R. H. (1987). Standardization of standard buffers by visible spectrometry. Anal. Chem. $513 \quad 59,1479-1481$.

514 Caldeira, K. and Wickett, M. E. (2003). Oceanography: anthropogenic carbon and ocean pH. $515 \quad$ Nature 425, 365-365.

516 Cattano, C., Calò, A., Di Franco, A., Firmamento, R., Quattrocchi, F., Sdiri, K., Guidetti, 517 P. and Milazzo, M. (2017). Ocean acidification does not impair predator recognition but 518 increases juvenile growth in a temperate wrasse off $\mathrm{CO}_{2}$ seeps. Mar. Environ. Res. 132, 3351940.

520 Checkley, D. M., Dickson, A. G., Takahashi, M., Radich, J. A., Eisenkolb, N. and Asch, R. (2009). Elevated $\mathrm{CO}_{2}$ enhances otolith growth in young fish. Science (80-. ). 324, 1683-

523 Chivers, D. P., Mccormick, M. I., Nilsson, G. E., Munday, P. L., Watson, S. A., Meekan, M. G., Mitchell, M. D., Corkill, K. C. and Ferrari, M. C. O. (2014). Impaired learning of predators and lower prey survival under elevated $\mathrm{CO}_{2}$ : a consequence of neurotransmitter interference. Glob. Chang. Biol. 20, 515-522.

Coll-Lladó, C., Giebichenstein, J., Webb, P. B., Bridges, C. R. and De La Serrana, D. G. (2018). Ocean acidification promotes otolith growth and calcite deposition in gilthead sea bream (Sparus aurata) larvae. Sci. Rep. 8, 1-10.

Doney, S. C., Fabry, V. J., Feely, R. A. and Kleypas, J. A. (2009). Ocean acidification: the other $\mathrm{CO}_{2}$ problem. Ann. Rev. Mar. Sci. 1, 169-192.

Esbaugh, A. J., Heuer, R. and Grosell, M. (2012). Impacts of ocean acidification on respiratory gas exchange and acid-base balance in a marine teleost, Opsanus beta. J. Comp. Physiol. B Biochem. Syst. Environ. Physiol. 182, 921-934.

Fabricius, K. E. (2005). Effects of terrestrial runoff on the ecology of corals and coral reefs:

Fabry, V. J., Seibel, B. A., Feely, R. A., Fabry, J. C. O. and Fabry, V. J. (2008). Impacts of ocean acidification on marine fauna and ecosystem processes. ICES J. Mar. Sci. 65, 414432.

Faria, A. M., Filipe, S., Lopes, A. F., Oliveira, A. P., Gonçalves, E. J. and Ribeiro, L. (2017). Effects of high $\mathrm{pCO}_{2}$ on early life development of pelagic spawning marine fish. Mar. 
542

543

544

545

546

547

548

Freshw. Res. 68.

Fekete, D. M. (2003). Rocks that roll zebrafish. Science 302, 241-2.

Nakamura Filho, A., Almeida, A. C. de, Riera, H. E., Araújo, J. L. F. de, Gouveia, V. J. P., Carvalho, M. D. de and Cardoso, A. V. (2014). Polymorphism of $\mathrm{CaCO}_{3}$ and microstructure of the shell of a Brazilian invasive mollusc (Limnoperna fortunei). Mater. Res. 17, 15-22.

Franke, A. and Clemmesen, C. (2011). Effect of ocean acidification on early life stages of Atlantic herring (Clupea harengus L.). Biogeosciences 8, 3697-3707.

Froese, R. and Pauly, D. (2018). Fishbase. FishBase.

Frommel, A. Y., Schubert, A., Piatkowski, U. and Clemmesen, C. (2013). Egg and early larval stages of Baltic cod, Gadus morhua, are robust to high levels of ocean acidification. Mar. Biol. 160, 1825-1834.

Gagliano, M., Depczynski, M., Simpson, S. D. and Moore, J. A. (2008). Dispersal without errors: symmetrical ears tune into the right frequency for survival. Proc. R. Soc. B Biol. Sci. 275, 527-534.

Gattuso, J. and Buddemeier, R. W. (2000). Calcification and $\mathrm{CO}_{2}$. Nature 407, 311-313.

Gaylord, B., Kroeker, K. J., Sunday, J. M., Anderson, K. M., Barry, J. P., Brown, N. E., Connell, S. D., Dupont, S., Fabricius, K. E., Hall-Spencer, J. M., Klinger, T., Milazzo, M., Munday, P.L., Russell, B.D., Sanford, E., Schreiber, S.J., Thiyagarajan, V., Vaughan, M.L.H., Widdicombe, S., and Harley, C.D.G. (2015). Ocean acidification through the lens of ecological theory. Ecology 96, 3-15.

Grosell, M. (2011). Intestinal anion exchange in marine teleosts is involved in osmoregulation and contributes to the oceanic inorganic carbon cycle. Acta Physiol. (Oxf). 202, 421-434.

Hamilton, T. J., Holcombe, A. and Tresguerres, M. (2013). CO $\mathrm{CO}_{2}$-induced ocean acidification increases anxiety in Rockfish via alteration of $\mathrm{GABA}_{\mathrm{A}}$ receptor functioning. Proc. R. Soc. B Biol. Sci. 281, 20132509-20132509.

Hendriks, I. E., Duarte, C. M. and Álvarez, M. (2010). Vulnerability of marine biodiversity to ocean acidification: a meta-analysis. Estuar. Coast. Shelf Sci. 86, 157-164.

Heuer, R. M. and Grosell, M. (2014). Physiological impacts of elevated carbon dioxide and ocean acidification on fish. AJP Regul. Integr. Comp. Physiol. 307, R1061-R1084.

Hilbig, R., Anken, R. H., Sonntag, G., Höhne, S., Henneberg, J., Kretschmer, N. and 
573

574

575

576

577

578

579

580

581

582

583

584

585

586

587

588

589

590

591

592

593

594

595

596

597

598

599

600

601

602

603

Rahmann, H. (2002). Effects of altered gravity on the swimming behaviour of fish. $A d v$. Sp. Res. 30, 835-841.

Hoegh-Guldberg, O., Poloczanska, E. S., Skirving, W. and Dove, S. (2017). Coral reef ecosystems under climate change and ocean acidification. Front. Mar. Sci. 4.

Hurst, T. P., Fernandez, E. R., Mathis, J. T., Miller, J. A., Stinson, C. M. and Ahgeak, E. F. (2012). Resiliency of juvenile walleye pollock to projected levels of ocean acidification. Aquat. Biol. 17, 247-259.

IPCC (2013). Climate Change 2013: The Physical Science Basis. Contribution of Working Group I to the Fifth Assessment Report of the Intergovernmental Panel on Climate Change. (ed. Stocker, T. F.), Qin, D.), Plattner, G.-K.), Tignor, M.), Allen, S. K.), Boschung, J.), Nauels, A.), Xia, Y.), V., B.), and P.M., M.).

Ishimatsu, A., Kikkawa, T., Hayashi, M., Lee, K.-S. and Kita, J. (2004). Effects of $\mathrm{CO}_{2}$ on marine fish: larvae and adults. J. Oceanogr. 60, 731-741.

Ishimatsu, A., Hayashi, M. and Kikkawa, T. (2008). Fishes in high- $\mathrm{CO}_{2}$, acidified oceans. Mar. Ecol. Prog. Ser. 373, 295-302.

Jarrold, M. D. and Munday, P. L. (2018). Diel $\mathrm{CO}_{2}$ cycles do not modify juvenile growth, survival and otolith development in two coral reef fish under ocean acidification. Mar. Biol. $165,1-12$.

Kikkawa, T., Ishimatsu, A. and Kita, J. (2003). Acute $\mathrm{CO}_{2}$ tolerance during the early developmental stages of four marine teleosts. Environ. Toxicol. 18, 375-382.

Kikkawa, T., Kita, J. and Ishimatsu, A. (2004). Comparison of the lethal effect of $\mathrm{CO}_{2}$ and acidification on red sea bream (Pagrus major) during the early developmental stages. Mar. Pollut. Bull. 48, 108-110.

Kroeker, K. J., Micheli, F. and Gambi, M. C. (2012). Ocean acidification causes ecosystem shifts via altered competitive interactions. Nat. Clim. Chang. 3, 156-159.

Kroeker, K. J., Kordas, R. L., Crim, R., Hendriks, I. E., Ramajo, L., Singh, G. S., Duarte, C. M. and Gattuso, J. P. (2013). Impacts of ocean acidification on marine organisms: quantifying sensitivities and interaction with warming. Glob. Chang. Biol. 19, 1884-1896.

Lai, F., Jutfelt, F. and Nilsson, G. E. (2015). Altered neurotransmitter function in $\mathrm{CO}_{2}$-exposed stickleback (Gasterosteus aculeatus): a temperate model species for ocean acidification research. Conserv. Physiol. 3, 1-6. 
604 Lazic, S. E. (2008). Why we should use simpler models if the data allow this: relevance for

605

606

607

608

609

610

611

612

613

614

615

616

617

618

619

620

621

622

623

624

625

626

627

628

629

630

631

632

633

634

ANOVA designs in experimental biology. BMC Physiol. 8, 1-7.

Le Quéré, C., Takahashi, T., Buitenhuis, E. T., Rödenbeck, C. and Sutherland, S. C. (2010).

Impact of climate change and variability on the global oceanic sink of $\mathrm{CO}_{2}$. Global Biogeochem. Cycles 24, n/a-n/a.

Lychakov, D. V. and Rebane, Y. T. (2005). Fish otolith mass asymmetry: Morphometry and influence on acoustic functionality. Hear. Res. 201, 55-69.

Ma, T., Kuroki, M., Miller, M. J., Ishida, R. and Tsukamoto, K. (2008). Morphology and microchemistry of abnormal otoliths in the ayu, Plecoglossus altivelis. Environ. Biol. Fishes 83, $155-167$.

Maneja, R. H., Frommel, A. Y., Geffen, A. J., Folkvord, A., Piatkowski, U., Chang, M. Y. and Clemmesen, C. (2013). Effects of ocean acidification on the calcification of otoliths of larval Atlantic cod Gadus morhua. Mar. Ecol. Prog. Ser. 477, 251-258.

Martino, J., Doubleday, Z. A., Woodcock, S. H. and Gillanders, B. M. (2017). Elevated carbon dioxide and temperature affects otolith development, but not chemistry, in a diadromous fish. J. Exp. Mar. Bio. Ecol. 495, 57-64.

Martins, S. I. G. (2017). Impacts of $\mathrm{CO}_{2}$-induced ocean acidification on predator detection ability and developementof temperate fish. PhD thesis, ISPA - Instituto Universitário de Ciências Psicológicas, Sociais e da Vida, Lisboa, Portugal.

McCormick, M. I. (1999). Delayed metamorphosis of a tropical reef fish (Acanthurus triostegus): A field experiment. Mar. Ecol. Prog. Ser. 176, 25-38.

Mikaloff Fletcher, S. E., Gruber, N., Jacobson, A. R., Doney, S. C., Dutkiewicz, S., Gerber, M., Follows, M., Joos, F., Lindsay, K., Menemenlis, D., Mouchet, A., Müller, S.A., and Sarmiento, J.L. (2006). Inverse estimates of anthropogenic $\mathrm{CO}_{2}$ uptake, transport, and storage by the ocean. Global Biogeochem. Cycles 20, 1-16.

Millero, F. J., Zhang, J. Z., Fiol, S., Sotolongo, S., Roy, R. N., Lee, K. and Mane, S. (1993). The use of buffers to measure the $\mathrm{pH}$ of seawater. Mar. Chem. 44, 143-152.

Mirasole, A., Gillanders, B. M., Reis-Santos, P., Grassa, F., Capasso, G., Scopelliti, G., Mazzola, A. and Vizzini, S. (2017). The influence of high $\mathrm{pCO}_{2}$ on otolith shape, chemical and carbon isotope composition of six coastal fish species in a Mediterranean shallow $\mathrm{CO}_{2}$ vent. Mar. Biol. 164, 1-15. 
635 Moyle, P. B. and Cech, J. J. (2004). Fishes, An Introduction to Ichtyology. 5th ed. (ed. Lee, C.),

636

637

638

639

640

641

642

643

644

645

646

647

648

649

650

651

652

653

654

655

656

657

658

659

660

661

662

663

664

665

Chung, T.), Kuhl, M.), and Bradley, K.) San Francisco: Pearson Benjamin Cummings.

Mu, J., Jin, F., Wang, J., Zheng, N., Cong, Y. and Wang, J. Y. (2015). Effects of $\mathrm{CO}_{2}$-driven ocean acidification on early life stages of marine medaka (Oryzias melastigma). Biogeosciences 12, 3861-3868.

Munday, P. L., Jones, G. P., Pratchett, M. S. and Williams, A. J. (2008). Climate change and the future for coral reef fishes. Fish Fish. 9, 261-285.

Munday, P. L., Crawley, N. E. and Nilsson, G. E. (2009). Interacting effects of elevated temperature and ocean acidification on the aerobic performance of coral reef fishes. Mar. Ecol. Prog. Ser. 388, 235-242.

Munday, P. L., Gagliano, M., Donelson, J. M., Dixson, D. L. and Thorrold, S. R. (2011a). Ocean acidification does not affect the early life history development of a tropical marine fish. Mar. Ecol. Prog. Ser. 423, 211-221.

Munday, P. L., Hernaman, V., Dixson, D. L. and Thorrold, S. R. (2011b). Effect of ocean acidification on otolith development in larvae of a tropical marine fish. Biogeosciences $\mathbf{8}$, $1631-1641$.

Munday, P. L., McCormick, M. I., Meekan, M. G., Dixson, D. L., Watson, S., Ferrari, M. C. O. and Chivers, D. P. (2012). Selective mortality associated with variation on $\mathrm{CO}_{2}$ tolerance in a marine fish. Ocean Acidif. 1, 1-5.

Nilsson, G. E., Dixson, D. L., Domenici, P., McCormick, M. I., Sørensen, C., Watson, S.-A. and Munday, P. L. (2012). Near-future carbon dioxide levels alter fish behaviour by interfering with neurotransmitter function. Nat. Clim. Chang. 2, 201-204.

Norman, G. (2010). Likert scales, levels of measurement and the "laws" of statistics. Adv. Heal. Sci. Educ. 15, 625-632.

Ohnishi, K., Yamamoto, T., Ogawa, Y., Takahashi, A., Yamashita, M. and Ohnishi, T. (2002). High transmittance of X-rays in the utricular otolith of upside-down swimming catfish, Synodontis nigriventris. Biol. Sci. Space. 16, 18-21.

Orr, J. C., Fabry, V. J., Aumont, O., Bopp, L., Doney, S. C., Feely, R. A., Gnanadesikan, A., Gruber, N., Ishida, A., Joos, F., Key, R.M., Lindsay, K., Maier-Reimer, E., Matear, R., Monfray, P., Mouchet, A., Najjar, R.G., Plattner, G.-K., Rodgers, K.B., Sabine, C.L., Sarmiento, J.L., Schlitzer, R., Slater, R.D., Totterdell, I.J., Weirig, M.-F., 
666

667

668

669

670

671

672

673

674

675

676

677

678

Yamanaka, Y., and Yool, A. (2005). Anthropogenic ocean acidification over the twentyfirst century and its impact on calcifying organisms. Nature 437, 681-686.

Oxman, D. S., Barnett-Johnson, R., Smith, M. E., Coffin, A., Miller, D. L., Josephson, R. and Popper, A. N. (2007). The effect of vaterite deposition on sound reception, ototlith morphology, and inner ear sensory epithelia in hatchery-reared chinook salmon (Oncorhynchus tshawytscha). Can. J. Fish. Aquat. Sci. 64, 1469-1478.

Panella, G. (1971). Fish otoliths: daily growth layers and periodical patterns. Science (80-. ). 173, 1124-1127.

Perry, D. M., Redman, D. H., Widman, J. C., Meseck, S., King, A. and Pereira, J. J. (2015). Effect of ocean acidification on growth and otolith condition of juvenile scup, Stenotomus chrysops. Ecol. Evol. 5, 4187-4196.

Pimentel, M. S., Faleiro, F., Dionisio, G., Repolho, T., Pousao-Ferreira, P., Machado, J. and Rosa, R. (2014). Defective skeletogenesis and oversized otoliths in fish early stages in a changing ocean. J. Exp. Biol. 217, 2062-2070.

Popper, A. N. and Fay, R. R. (1993). Sound detection and processing by fish: critical review and major research questions. Brain. Behav. Evol.

Queirós, A. M., Fernandes, J. A., Faulwetter, S., Nunes, J., Rastrick, S. P. S., Mieszkowska, N., Artioli, Y., Yool, A., Calosi, P., Arvanitidis, C., Findlay, H.S., Barange, M., Cheung, W.W.L., and Widdicombe, S. (2015). Scaling up experimental ocean acidification and warming research: From individuals to the ecosystem. Glob. Chang. Biol. 21, 130-143.

Reimer, T., Dempster, T., Warren-Myers, F., Jensen, A. J. and Swearer, S. E. (2016). High prevalence of vaterite in sagittal otoliths causes hearing impairment in farmed fish. Sci. Rep. 6, 25249.

Réveillac, E., Lacoue-Labarthe, T., Oberhänsli, F., Teyssié, J. L., Jeffree, R., Gattuso, J. P. and Martin, S. (2015). Ocean acidification reshapes the otolith-body allometry of growth in juvenile sea bream. J. Exp. Mar. Bio. Ecol. 463, 87-94.

Ries, J. B., Cohen, A. L. and McCorkle, D. C. (2009). Marine calcifiers exhibit mixed responses to $\mathrm{CO}_{2}$-induced ocean acidification. Geology 37, 1131-1134.

Rossi, T., Nagelkerken, I., Simpson, S. D., Pistevos, J. C. A., Watson, S.-A., Merillet, L., Fraser, P., Munday, P. L. and Connell, S. D. (2015). Ocean acidification boosts larval 
697

698

699

700

701

702

703

704

705

706

707

708

709

710

711

712

713

714

715

716

717

718

719

720

721

722

723

724

725

fish development but reduces the window of opportunity for successful settlement. Proc. R. Soc. B Biol. Sci. 282, 20151954.

Schade, F. M., Clemmesen, C. and Mathias Wegner, K. (2014). Within- and transgenerational effects of ocean acidification on life history of marine three-spined stickleback (Gasterosteus aculeatus). Mar. Biol. 161, 1667-1676.

Seibel, B. A., Maas, A. E. and Dierssen, H. M. (2012). Energetic plasticity underlies a variable response to ocean acidification in the pteropod, Limacina helicina antarctica. PLoS One 7, e30464.

Shen, S. G., Chen, F., Schoppik, D. E. and Checkley, D. M. (2016). Otolith size and the vestibulo-ocular reflex of larvae of white seabass Atractoscion nobilis at high $\mathrm{pCO}_{2}$. Mar. Ecol. Prog. Ser. 553, 173-182.

Simpson, S. D., Munday, P. L., Wittenrich, M. L., Manassa, R., Dixson, D. L., Gagliano, M. and Yan, H. Y. (2011). Ocean acidification erodes crucial auditory behaviour in a marine fish. Biol. Lett. 7, 917-920.

Söllner, C. (2003). Control of Crystal Size and Lattice Formation by Starmaker in Otolith Biomineralization. Science (80-. ). 302, 282-286.

Victor, B. C. (1986). Delayed metamorphosis with reduced larval growth in a coral reef fish (Thalassoma bifasciatum). Can. J. Fish. Aquat. Sci. 43, 1208-1213.

Vogel, N., Fabricius, K. E., Strahl, J., Noonan, S. H. C., Wild, C. and Uthicke, S. (2015). Calcareous green alga Halimeda tolerates ocean acidification conditions at tropical carbon dioxide seeps. Limnol. Oceanogr. 60, 263-275.

Wallace, R. B., Baumann, H., Grear, J. S., Aller, R. C. and Gobler, C. J. (2014). Coastal ocean acidification: The other eutrophication problem. Estuar. Coast. Shelf Sci. 148, 1-13.

Wilcox-Freeburg, E. D. (2014). Exploring the link between otolith growth and function along the biological continuum in the context of ocean acidification. PhD thesis, University of Massachusetts Boston, Boston, MA.

Wilcox-Freeburg, E., Rhyne, A., Robinson, W. E., Tlusty, M., Bourque, B. and Hannigan, R. E. (2013). A comparison of two pH-stat carbon dioxide dosing systems for ocean acidification experiments. Limnol. Oceanogr. Methods 11, 485-494. 


\section{Table $\mathbf{1}$ (on next page)}

Summary of observed ocean acidification impacts on otolith morphology.

In the 'Metrics' column, $\mathrm{S}$ denotes effects of $\mathrm{pCO}_{2}$ on sagittae and $\mathrm{L}$ denotes effects on lapilli. Metrics that increased at elevated $\mathrm{pCO}_{2}$ are designated with an up arrow; metrics that decreased at elevated $\mathrm{pCO}_{2}$ are designated with a down arrow. The 'Min. Effect' column represents the minimum $\mathrm{pCO}_{2}$ threshold for which any effect was observed, reported to the decimal place published. 'Life stage, although unlisted in the manuscript, is here inferred from fish standard length (SL). ${ }^{2} \mathrm{pCO}_{2}$ is unlisted in the manuscript and cannot be calculated without additional seawater carbonate chemistry parameter(s). 


\begin{tabular}{|c|c|c|c|c|}
\hline Citation & Species & Life Stage & Metrics & $\begin{array}{c}\text { Min. Effect } \\
\quad(\mu \mathrm{atm})\end{array}$ \\
\hline Checkley et al. 2009 & Atractoscion nobilis & Larval & $\uparrow \mathrm{S}$ Area & 993 \\
\hline Munday et al. 2011b & Amphiprion percula & Larval & $\uparrow \mathrm{S}$ Area, Length & 1721.4 \\
\hline Hurst et al. 2012 & Theragra chalcogramma & Juvenile & $\uparrow \mathrm{S}$ Mean Incr. Width & 478 \\
\hline Bignami et al. 2013a,b & Rachycentron canadum & Larval & $\begin{array}{c}\uparrow \text { S Mass; } \uparrow \text { S,L Area, } \\
\text { Vol., Dens., } \downarrow \\
\text { Area/Vol. }\end{array}$ & 800 \\
\hline Maneja et al. 2013 & Gadus morhua & Larval & $\begin{array}{c}\uparrow \mathrm{S}, \mathrm{L} \text { Area; } \uparrow \mathrm{S} \\
\text { Roundness; } \downarrow \mathrm{L} \\
\text { Roundness }\end{array}$ & 1800 \\
\hline Bignami et al. 2014 & Coryphaena hippurus & Larval & $\uparrow \mathrm{S}, \mathrm{L}$ Area & 1190 \\
\hline Pimentel et al. 2014 & Solea senegalensis & Larval & $\uparrow \mathrm{S}$ Area & 1600 \\
\hline Schade et al. 2014 & Gasterosteus aculeatus & Juvenile & $\uparrow \mathrm{S}$ Area & 1167 \\
\hline Mu et al. 2015 & Oryzias melastigma & Larval & $\downarrow$ S Area & 2372.6 \\
\hline Réveillac et al. 2015 & Sparus aurata & Juvenile & $\begin{array}{c}\uparrow \mathrm{S} \text { Calc. Rate, } \\
\text { Area/TL }, \downarrow \text { Roundness }\end{array}$ & 726 \\
\hline Shen et al. 2016 & Atractoscion nobilis & Larval & $\uparrow \mathrm{S}, \mathrm{L}$ Area & 2500 \\
\hline \multirow[t]{3}{*}{ Faria et al. 2017} & Argyrosomus regius & Larval & $\begin{array}{c}\uparrow \mathrm{S} \text { Area, Perimeter, } \\
\text { Width }\end{array}$ & 1900 \\
\hline & Diplodus sargus & Larval & $\uparrow \mathrm{S}$ Area, Perimeter & 1100 \\
\hline & Solea senegalensis & Larval & $\uparrow \mathrm{S}$ Area, Perimeter & 1900 \\
\hline Martins 2017 & $\begin{array}{l}\text { Lepadogaster } \\
\text { lepadogaster }\end{array}$ & Larval & $\uparrow \mathrm{S}$ Roundness & 1541.68 \\
\hline \multirow[t]{2}{*}{ Mirasole et al. 2017} & Diplodus vulgaris & Juvenile $^{1}$ & $\begin{array}{c}\uparrow \text { S Relative Length; } \\
\text { Altered Shape }\end{array}$ & $\mathrm{pH} 7.8^{2}$ \\
\hline & Gobius bucchichi & Adult $^{1}$ & S Altered Shape & $\mathrm{pH} 7.8^{2}$ \\
\hline Coll-Lladó et al. 2018 & Sparus aurata & Larval & $\begin{array}{c}\uparrow \mathrm{S}, \mathrm{L} \text { Area, Perimeter, } \\
\text { Shape Irregularity }\end{array}$ & 1159 \\
\hline
\end{tabular}




\section{Table 2 (on next page)}

Seawater carbonate chemistry parameters.

Values represent aquaria means ( $n=3$ for each treatment); standard deviations listed in parentheses for measured parameters. 


\begin{tabular}{|c|c|c|c|c|c|c|}
\hline $\begin{array}{c}\text { Treatment } \\
\left(\mathrm{pH}_{\mathrm{T}}\right)\end{array}$ & $\mathrm{S}(\mathrm{ppt})$ & $\mathrm{T}\left({ }^{\circ} \mathrm{C}\right)$ & $\begin{array}{c}\mathrm{A}_{\mathrm{T}}(\mu \mathrm{mol} \\
\left.\mathrm{kg}^{-1}\right)\end{array}$ & $\begin{array}{c}\mathrm{DIC}(\mu \mathrm{mol} \\
\left.\mathrm{kg}^{-1}\right)\end{array}$ & $\begin{array}{c}\mathrm{pCO}_{2} \\
(\mu \mathrm{atm})\end{array}$ & $\Omega_{\mathrm{Ar}}$ \\
\hline $8.16(0.04)$ & 35.00 & 28.20 & 2440 & 2018 & 299.4 & 4.84 \\
$(0.30)$ & $(0.40)$ & $(147)$ & & & \\
\hline $7.80(0.01)$ & 35.00 & 28.20 & 2440 & 2237 & 825.5 & 2.54 \\
& $(0.30)$ & $(0.40)$ & $(152)$ & & & \\
\hline $7.60(0.01)$ & 35.00 & 28.30 & 2432 & 2318 & 1384.3 & 1.70 \\
& $(0.30)$ & $(0.40)$ & $(140)$ & & & \\
\hline $7.30(0.01)$ & 35.00 & 28.20 & 2418 & 2415 & 2897.0 & 0.89 \\
& $(0.30)$ & $(0.40)$ & $(140)$ & & & \\
\hline
\end{tabular}

1 


\section{Table 3 (on next page)}

Component variances and loadings.

Loadings corresponding to various Amphiprion clarkii otolith morphological parameters, the variance of which composes the rotated components in Fig. 2 and other components excluded from the analysis. Also included are the variances associated with each component and the total variance associated with components. Asterisks signify which components are related to $\mathrm{pCO}_{2}(p<0.05)$ and which variables are strongly associated with each of those components $(r \geq 0.50)$. 


\begin{tabular}{|c|c|c|c|c|c|c|c|}
\hline Otolith & Component & $\begin{array}{l}\text { Variance } \\
(\%)\end{array}$ & Area/SL & Perimeter/SL & Circularity & $\begin{array}{l}\text { Lateral } \\
\text { Development }\end{array}$ & $\begin{array}{l}\text { Percent } \\
\text { Visible } \\
\text { Crystals }\end{array}$ \\
\hline \multirow{3}{*}{$\begin{array}{l}\text { Left } \\
\text { Sagittae }\end{array}$} & $\mathrm{RC} 1 *$ & 47 & $0.62 *$ & 0.37 & 0.05 & $0.97 *$ & $0.94 *$ \\
\hline & $\mathrm{RC} 2$ & 37 & 0.61 & 0.85 & -0.86 & 0.08 & 0.17 \\
\hline & Total & 84 & & & & & \\
\hline \multirow{3}{*}{$\begin{array}{l}\text { Right } \\
\text { Sagittae }\end{array}$} & RC1* & 59 & $0.77 *$ & $0.72^{*}$ & 0.00 & $0.95^{*}$ & $0.96^{*}$ \\
\hline & $\mathrm{RC} 2$ & 29 & 0.39 & 0.61 & -0.94 & 0.06 & -0.07 \\
\hline & Total & 88 & & & & & \\
\hline \multirow{3}{*}{$\begin{array}{l}\text { Left } \\
\text { Lapilli }\end{array}$} & $\mathrm{RC} 1$ & 46 & -0.12 & -0.30 & 0.67 & 0.90 & 0.96 \\
\hline & $\mathrm{RC} 2 *$ & 36 & $0.89^{*}$ & $0.90^{*}$ & -0.32 & -0.29 & -0.03 \\
\hline & Total & 82 & & & & & \\
\hline \multirow{3}{*}{$\begin{array}{l}\text { Right } \\
\text { Lapilli }\end{array}$} & $\mathrm{RC} 1$ & 44 & 0.88 & 0.99 & -0.65 & -0.08 & -0.01 \\
\hline & $\mathrm{RC} 2 *$ & 34 & 0.02 & 0.06 & 0.31 & $0.88^{*}$ & $0.92^{*}$ \\
\hline & Total & 78 & & & & & \\
\hline \multirow{3}{*}{$\begin{array}{l}\text { Left } \\
\text { Asterisci }\end{array}$} & $\mathrm{RC} 1$ & 44 & 0.81 & 0.81 & -0.15 & -0.75 & -0.54 \\
\hline & $\mathrm{RC} 2 *$ & 34 & -0.11 & $0.53^{*}$ & $-0.92 *$ & 0.04 & $0.73^{*}$ \\
\hline & Total & 78 & & & & & \\
\hline \multirow{3}{*}{$\begin{array}{l}\text { Right } \\
\text { Asterisci }\end{array}$} & $\mathrm{RC} 1$ & 50 & 0.89 & 0.98 & -0.73 & -0.06 & 0.48 \\
\hline & $\mathrm{RC} 2$ & 24 & -0.16 & 0.08 & -0.31 & 0.91 & 0.50 \\
\hline & Total & 74 & & & & & \\
\hline
\end{tabular}




\section{Table 4(on next page)}

Regression statistics.

Regression models are listed by row, including all models in the manuscript for which $\mathrm{pCO}_{2}$ predicted the response variable ( $p \leq 0.05)$, and truncated models with data from the 3,000 Matm $\mathrm{pCO}_{2} / \mathrm{pH} 7.30$ treatment excluded (designated by subscript $\mathrm{T}$ ). For the otolith morphological models, model name abbreviations are identical to those elsewhere in the manuscript (e.g., LS for Left Sagittae). FSC stands for Fish Settlement Competency (at 10 dph). FSL stands for Fish Standard Length. Component names (Comp.) are listed for otolith morphological models only. Statistics including degrees of freedom (DF), F-statistics (F), pvalues $(p)$, line equations, line slopes multiplied by $100\left(b_{1} * 100\right), 95 \%$ confidence intervals for slopes multiplied by $100(\mathrm{Cl} 100)$, and $\mathrm{R}^{2} \mathrm{~S}$ are listed. Only $\mathrm{DF}, \mathrm{F}$, and $\mathrm{p}$ are listed for truncated models, as the full models are considered to be more informative except for determining whether the $3,000 \mu$ atm $\mathrm{pCO}_{2} / \mathrm{pH} 7.30$ treatment disproportionately weighted them. Line slopes and confidence intervals should be read as "[response variable] increased by $\left[\mathrm{b}_{1} * 100\right]$ [units] for every 100 matm increase in $\mathrm{pCO}_{2}(95 \% \mathrm{Cl}$ : [Cl*100])". Line slopes and confidence intervals were excluded for polynomial (quadratic) models, as they are not as easily interpreted. ${ }^{1}$ For $\mathrm{FSC}$ and $\mathrm{FSC}_{\mathrm{T}}$, which are binomial logistic regression models, the values listed as $\mathrm{F}$ are actually $\chi^{2}$-statistics. 


\begin{tabular}{|c|c|c|c|c|c|c|c|c|}
\hline Model & Comp. & DF & $\mathrm{F}$ & $\mathrm{p}$ & Equation & $\mathrm{b}_{1} * 100$ & CI*100 & $\mathrm{R}^{2}$ \\
\hline LS & $\mathrm{RC1}$ & 1,10 & 11.98 & 0.0061 & $\mathrm{y}=(7.28 \mathrm{E}-4) \mathrm{x}-0.98$ & 0.07 & $0.03-0.12$ & 0.50 \\
\hline $\mathrm{LS}_{\mathrm{T}}$ & $\mathrm{RC} 1$ & 1,7 & 10.67 & 0.0137 & - & - & - & - \\
\hline $\mathrm{RS}$ & $\mathrm{RC} 1$ & 2,9 & 20.56 & 0.0004 & $\begin{array}{c}\mathrm{y}=(2.51 \mathrm{E}-3) \mathrm{x}-(5.08 \mathrm{E}-7) \mathrm{x}^{2}- \\
1.98)\end{array}$ & - & - & 0.78 \\
\hline $\mathrm{RS}_{\mathrm{T}}$ & $\mathrm{RC} 1$ & 2,6 & 14.64 & 0.0049 & - & - & - & - \\
\hline LL & $\mathrm{RC} 2$ & 2,9 & 10.47 & 0.0045 & $\begin{array}{c}\mathrm{y}=(3.48 \mathrm{E}-3) \mathrm{x}-(8.86 \mathrm{E}-7) \mathrm{x}^{2}- \\
2.25)\end{array}$ & - & - & 0.63 \\
\hline $\mathrm{LL}_{\mathrm{T}}$ & $\mathrm{RC} 2$ & 2,6 & 10.91 & 0.0100 & - & - & - & - \\
\hline $\mathrm{RL}$ & $\mathrm{RC} 2$ & 1,10 & 8.21 & 0.0168 & $y=(6.62 E-4) x-0.89$ & 0.07 & $0.01-0.12$ & 0.40 \\
\hline $\mathrm{RL}_{\mathrm{T}}$ & $\mathrm{RC} 2$ & 1,7 & 0.11 & 0.7489 & - & - & - & - \\
\hline LA & $\mathrm{RC} 2$ & 1,9 & 5.61 & 0.0420 & $y=(6.64 E-4) x-0.80$ & 0.07 & $0.00-0.13$ & 0.32 \\
\hline $\mathrm{LA}_{\mathrm{T}}$ & $\mathrm{RC} 2$ & 1,7 & 1.04 & 0.3423 & - & - & - & - \\
\hline FSC & - & 1,10 & $4.83^{1}$ & 0.0279 & $\operatorname{logit}(\pi)=(-3.81 \mathrm{E}-4) \mathrm{x}+2.31$ & 0.04 & $0.00-0.07$ & 0.38 \\
\hline $\mathrm{FSC}_{\mathrm{T}}$ & - & 1,7 & $7.26^{1}$ & 0.0071 & - & - & - & - \\
\hline FSL & - & 1,10 & 17.77 & 0.0018 & $y=(-1.31 E-4) x+6.85$ & 0.01 & $0.00-0.02$ & 0.60 \\
\hline $\mathrm{FSL}_{\mathrm{T}}$ & - & 1,7 & 2.43 & 0.1629 & - & - & - & - \\
\hline
\end{tabular}

1 


\section{Figure 1}

Mean unstandardized otolith metrics.

Summary of raw (fish-level) otolith morphological data including (A) Area, (B) Perimeter, (C) Circularity, (D) Lateral Development, and (E) Percent Visible Crystals by $\mathrm{pH} \mathrm{pH/pCO}$ treatment (legend) and otolith type/side. Otolith name abbreviations are identical to those elsewhere in the manuscript (e.g., LS for Left Sagittae). Bars represent combined means. Lines represent one (pooled) standard deviation.

\section{Mean Unstandardized Otolith Metrics}
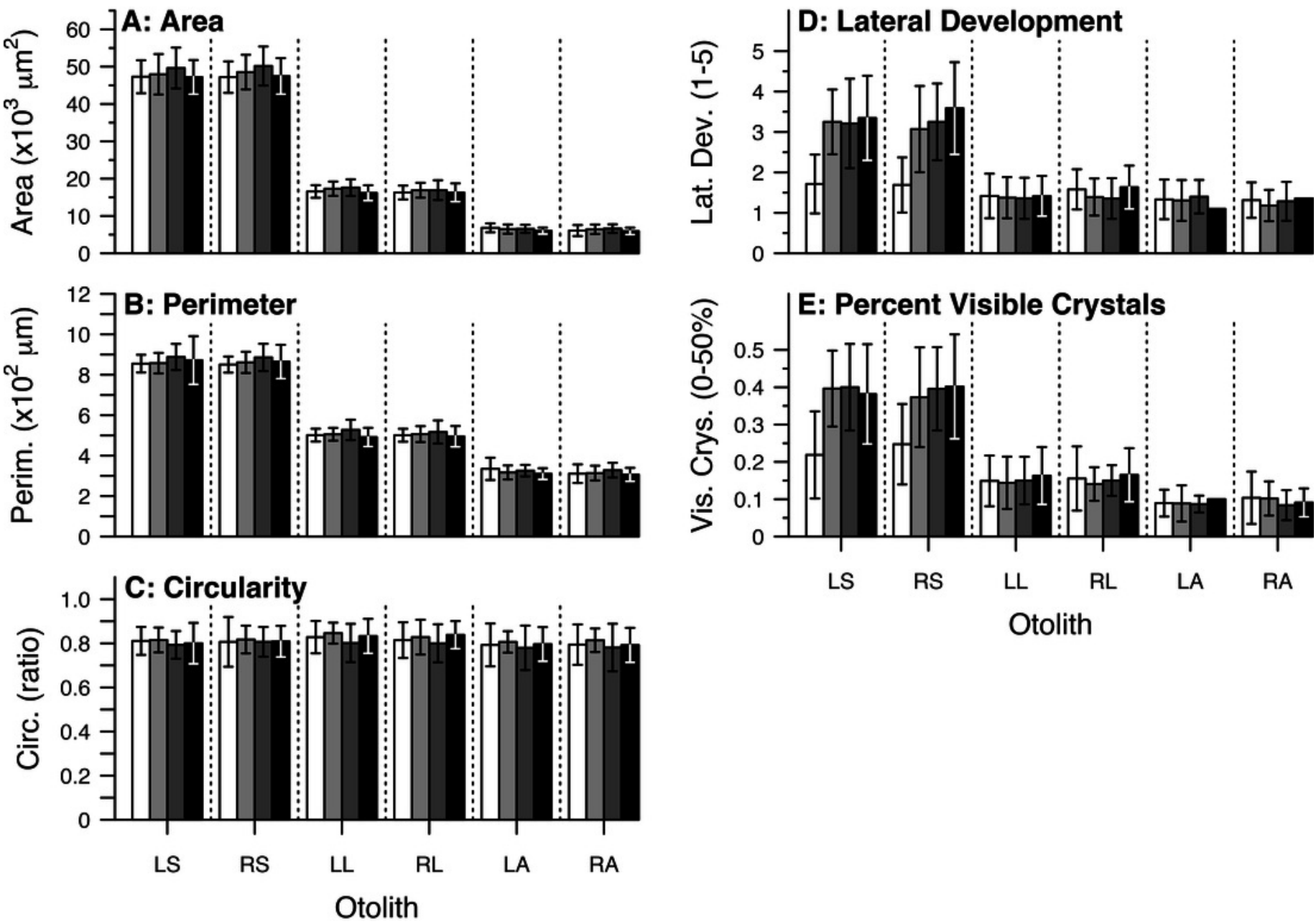

LS

RS

LL $\quad \mathrm{RL}$

LA

RA Otolith 


\section{Figure 2}

Otolith morphological metrics.

Regression lines (solid) and 95\% confidence bands (dotted) represent significant relations between $\mathrm{pH} / \mathrm{pCO}_{2}$ treatment (legend) and ( $\left.\mathrm{A}, \mathrm{B}, \mathrm{C}, \mathrm{D}, \mathrm{E}\right)$ rotated component (RC) scores representing Amphiprion clarkii otolith morphological variables, grouped by otolith type and side ( $A: p=0.0061 ; B: p=0.0004 ; C: p=0.0045 ; D: p=0.0168 ; E: p=0.0420$ ). Right asterisci components vs. $\mathrm{pCO}_{2}$ did not yield significant relations, but $\mathrm{RC} 2$ scores are plotted for illustrative consistency. Data points represent aquaria. $N=12, n=3$ except where (E) no data is available for an aquarium ( $\mathrm{N}=11, \mathrm{n}=2$ for $\mathrm{pH} 7.30$ treatment only). See Table 3 for otolith morphological variables and corresponding PCA loadings. 


\section{Otolith Morphological Metrics}
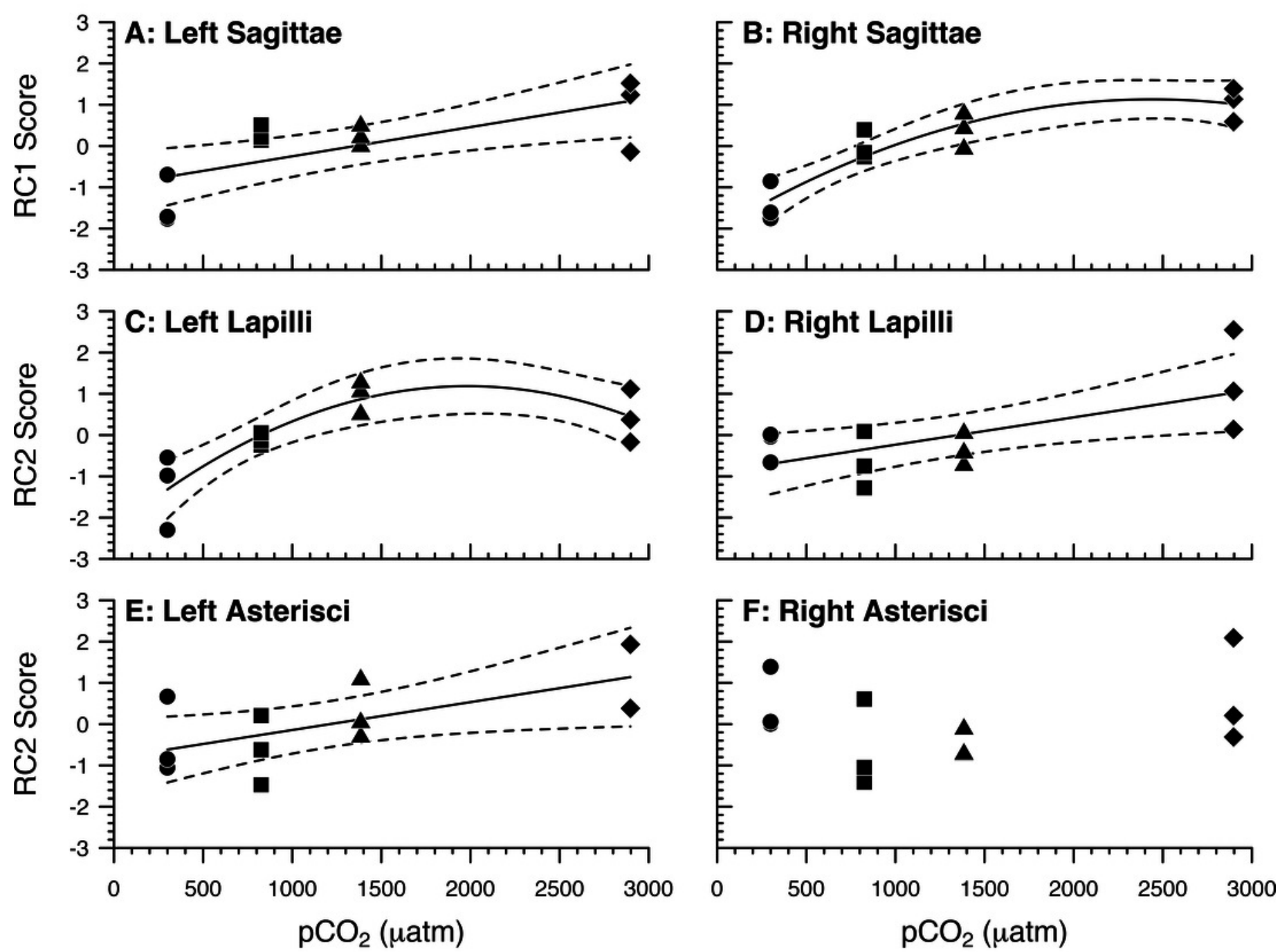

- $\mathrm{pH} 8.16 \backsim \mathrm{pH} 7.80 \wedge \mathrm{pH} 7.60 \bullet \mathrm{pH} 7.30$ 


\section{Figure 3}

Mean fish condition metrics.

Summary of raw (fish-level) fish condition data by $\mathrm{pH} / \mathrm{pCO}_{2}$ treatment (legend) including (A) Mortality, (B) Competency to Settle at 10 days post-hatch (dph), (C) Standard Length. Bars represent combined means. Lines represent one (pooled) standard deviation. 


\section{Mean Fish Condition Metrics}

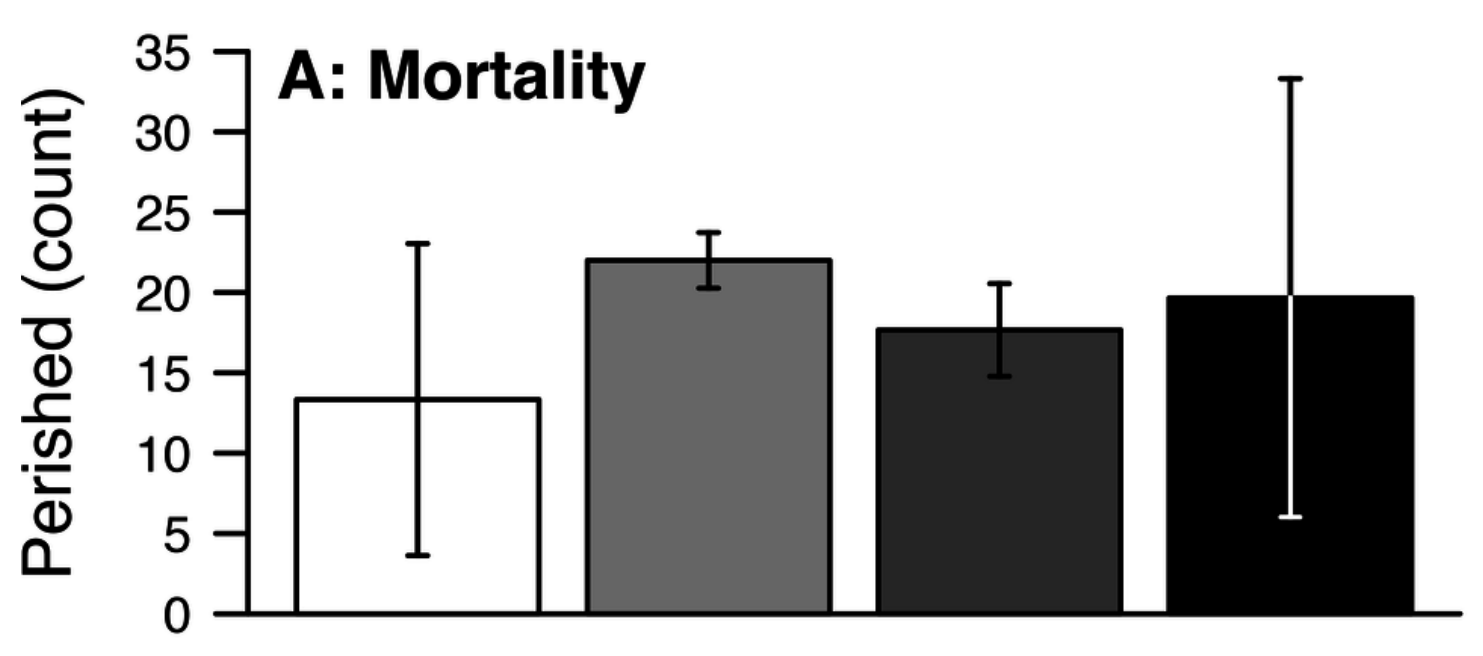

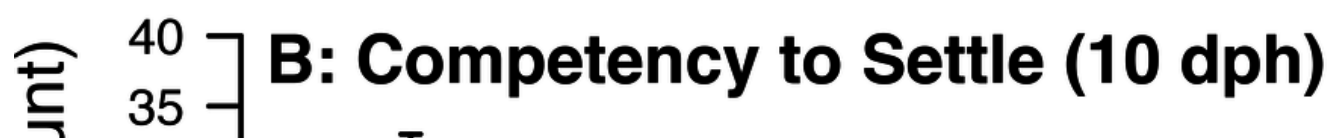
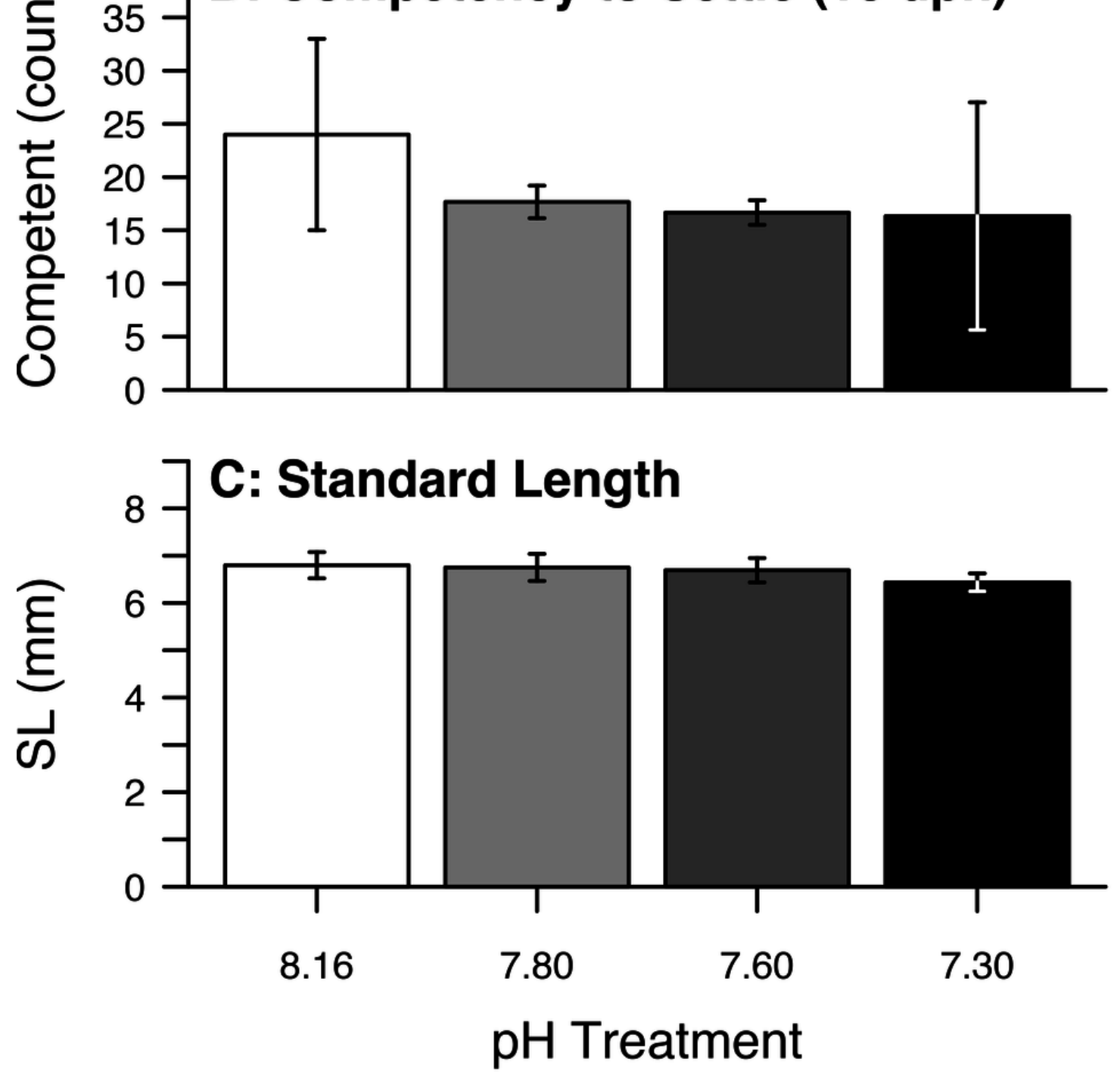


\section{Figure 4}

Fish condition metrics.

(A) Odds of Amphiprion clarkii mortality by $\mathrm{pH} / \mathrm{pCO}_{2}$ treatment (legend). Regression lines (solid) and 95\% confidence bands (dotted) represent significant relations between $\mathrm{pH} / \mathrm{pCO}_{2}$ treatment and (B) odds of on-time $A$. clarkii settlement $(p=0.0279)$; $(C) A$. clarkii standard length ( $p=0.0018$ ). Data points represent $(A, B)$ binomial proportions by aquarium; $(C)$ aquarium means. $\mathrm{N}=12, \mathrm{n}=3$ except where (B) $100 \%$ of fish in an aquarium settled on time ( $\mathrm{N}=10, \mathrm{n}=1$ for $\mathrm{pH} 7.80$ treatment only). 


\section{Fish Condition Metrics}
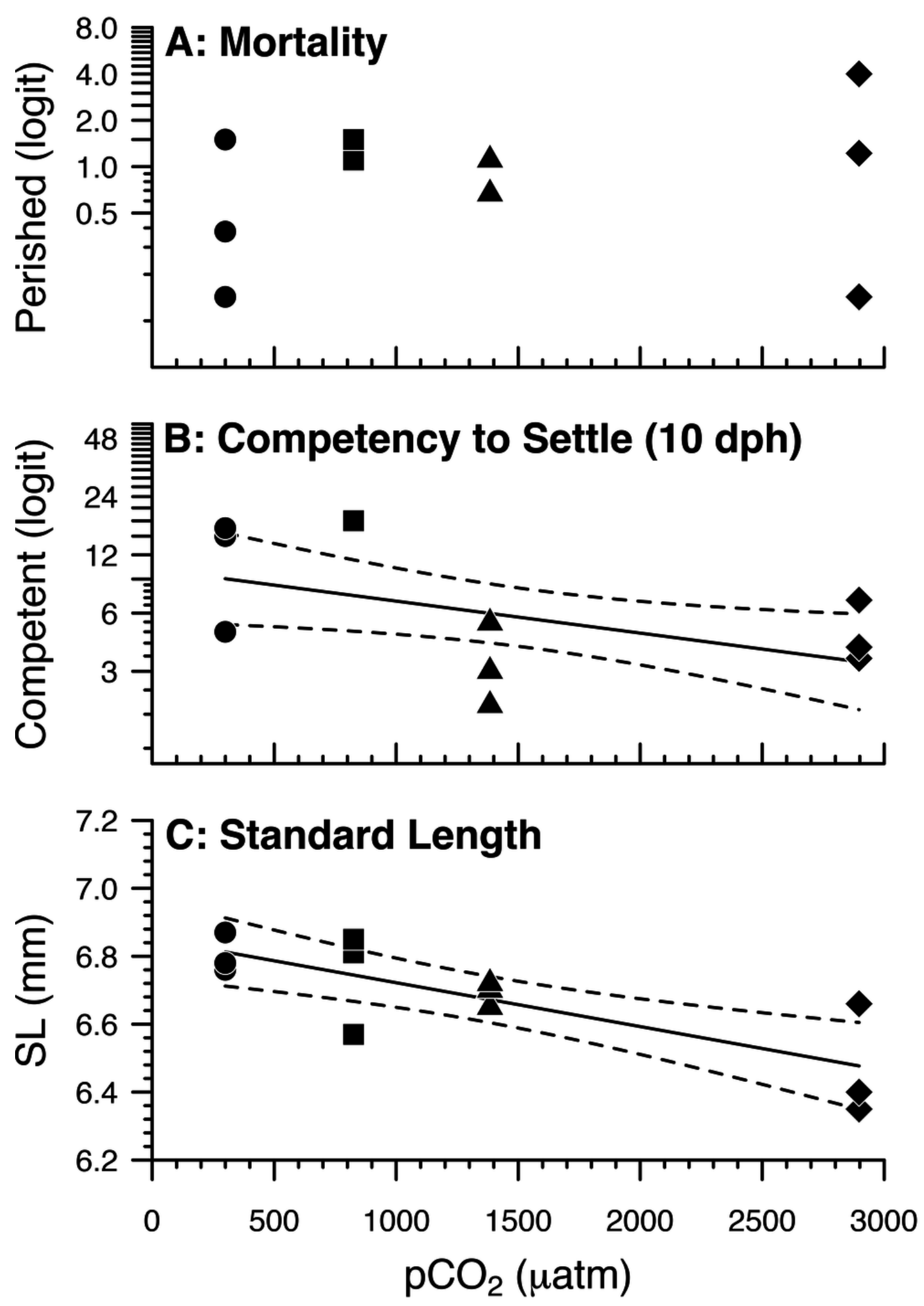

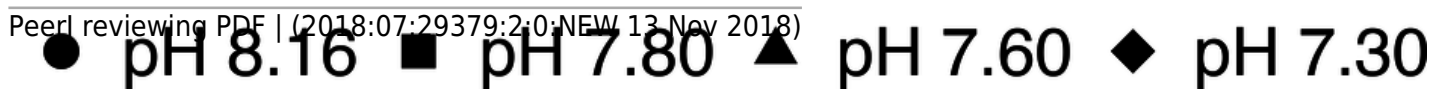

